\title{
Evaluation of Managerial Effectiveness of Lifelong Learning Services According to Trainees of Continuing Education Centres
}

\author{
Remzi YILDIRIM*a
}

\begin{tabular}{l}
\hline Article Info \\
\hline DOI: $10.14686 /$ buefad.417105 \\
\hline Article History: \\
Received 19.04.2018 \\
Accepted $\quad 08.10 .2018$ \\
Published $\quad 31.10 .2018$ \\
\hline Keywords: \\
Lifelong learning, \\
Managerial effectiveness, \\
Continuing education centres \\
\hline Article Type: \\
Research article \\
\hline
\end{tabular}

\begin{abstract}
This research was done to identify managerial effectiveness of continuing education centres that give service in universities within the scope of lifelong learning, according to trainee evaluations. Obtained results are expected to contribute lifelong learning and educational management field at theory and practice points. The research was conducted according to general survey pattern by using quantitative research techniques. 5 Likert type gradation scale used in research is the part of data collection tool named "SEMYE-VTA" towards trainees and it involves dimensions such as aim, organizational structure and process. The data were collected from continuing education centres of four universities chosen from Eskisehir, İzmir and Manisa provinces in 2016 spring term with the participation of 179 trainees. In analysis of evaluation of trainees towards stated dimensions, frequency values were used to show data distribution, averages were used to present common opinions of participants and standard deviation values were used to find criteria distribution and agreement levels. In construction of analysis according to variables such as age, gender and education status Mann Whitney U test and Kruskal Wallis test were used. According to obtained findings in presentation of counselling services in organizational structure dimension and in presentation of planned trainings a number of deficiencies showed up. Also during process, experienced deficiencies regarding physical conditions, were emphasized.
\end{abstract}

\section{Sürekli Eğitim Merkezi Kursiyerlerine Göre Yaşam Boyu Öğrenme Hizmetlerinin Yönetsel Etkililiğinin Değerlendirilmesi}

\begin{tabular}{l} 
Makale Bilgisi \\
\hline DOI:10.14686/buefad.417105 \\
\hline Makale \\
Geçmişişi: $\quad 19.04 .2018$ \\
Düzeltme $\quad 08.10 .2018$ \\
Kabul $\quad 31.10 .2018$ \\
\hline Anahtar Kelimeler: \\
Yaşam boyu öğrenme, \\
Yönetsel etkililik, \\
Sürekli eğitim merkezleri \\
\hline \\
\hline Makale Türü: \\
Araştırma makalesi \\
\hline
\end{tabular}

Öz

$\mathrm{Bu}$ araştırma, üniversitelerde yaşam boyu öğrenme kapsamında hizmet vermekte olan sürekli eğitim merkezlerinin yönetsel etkililiğini kursiyer değerlendirmelerine göre belirlemek amaciyla gerçekleştirilmiştir. Elde edilen sonuçların yaşam boyu öğrenme ve eğitim yönetimi alanına teori ve uygulama noktasında katkı sağlaması beklenmektedir. Araştırma nicel araştırma teknikleri kullanılarak tarama desenine göre yürütülmüştür. Araştırmada kullanılan 5'li Likert tipindeki derecelendirme ölçeği, "SEMYE-VTA" adlı veri toplama aracının kursiyerlere yönelik bölümü olup amaç, örgütsel yapı ve süreç biçimindeki boyutları kapsamaktadır. Veriler 2016 Bahar Döneminde Eskişehir, İzmir ve Manisa İllerinden seçilen dört üniversiteye ait sürekli eğitim merkezinden 179 kursiyerin katılımıyla toplanmıştır. Yaş, cinsiyet ve eğitim durumu şeklindeki değișkenlere göre analizlerin yapılmasında Mann Whitney U testi ve Kruskal Wallis testi kullanılmıştır. Elde edilen bulgulara göre örgütsel yap1 boyutunda danışma hizmetlerinin sunulmasında ve planlanan eğitimlerin tanıtılmasında bir takım eksiklikler ortaya çıkmıştır. Ayrıca süreç boyutunda fiziki koşullarla ilgili yaşanan eksiklikler vurgulanmıştır.

\footnotetext{
*Corresponding Author: yildirimremzi@ hotmail.com

${ }^{a}$ Lecturer Phd., Manisa Celal Bayar University, Manisa, Turkey, https://orcid.org/0000-0002-6918-5416
} 


\section{Introduction}

The knowledge of humankind and his skill of transferring this knowledge play a role in reaching today's information age. As a result of transferring knowledge, interpreting, developing, increasing and forming it, finding a meaning for it, making it tangible with human instead of keeping it in a book, a data bank or a computer programme, human being took his place in the centre in information society transformation process (Drucker, 1993). Educated human became an important necessity of information age.

Learning settings at various levels that can be an alternative to present education organizations in obtaining and transferring of information, showed up with information age. It can be said that all these learning opportunities are for fulfilling learning necessity that is known as lifelong learning. As Jarvis (2007) stated, lifelong learning is learning processes that humankind acquire in all its parts.

Completing compulsory education does not mean for individuals getting all training they require lifelong and within the scope of length of life. Social, economic and individual reasons (Güleç, Çelik ve Demirhan, 2012) that show up in various ways, oblige lifelong learning. Lifelong learning can be considered as a process that continues from birth to death (MacPhail, 2008).

In order to be a modern society and provide community development, demand for lifelong learner individuals equipped with knowledge, skills and behaviours necessary for age and institutions giving lifelong learning is on increase. It can be said that universities have important roles in terms of opportunities and accumulation of knowledge in today's world in which many learning opportunities are able to access in lifelong learning process. During historical process nothing preserved its structure just like the first day and showed change in time. Universities also have not been constant during historical process, they showed continuous change and development suitable to the philosophy and necessities of period. It is possible to gather properties of universities that are in effort of conducting scientific research studies and raising qualified people for society, in three categories until their appearance. Development of universities in historical process occurred as first, second and third generation (Wissema, 2009). For many year universities did not do anything except from giving vocational education aimed only raising professionalists (Yusuf, 2011). Increase of competition in industry and by adopting the idea of making innovations and inventions as an important solution for being afloat in this competition, the cooperation of university and industry showed up, accordingly universities focused on research and development activities apart from their higher education service. Universities that add social service function to their actual education and research functions later (Soran, Akkoyunlu ve Kavak, 2006), became important institutions for lifelong learning. Today it is possible to gather functions of universities into three groups as education, research and social service (Erdem, 2005). Increasing speed of globalization, aging population in developed countries and rapid technological changes (EUA, 2008), evoked universities and imposed lifelong learning on them. Lifelong learning will be a good opportunity for universities to be more concentric and more beneficial for society. Accordingly, the individuals living in information society can reach reliable knowledge sources via universities and will continue lifelong learning.

As it is in all organizational structures, it can be said that as educational organizations universities reveal their managerial effectiveness by fulfilling their duty. Arslan (2010) emphasized the importance of managerial effectiveness for educational organizations in being more productive and more successful. According to editing of Karsl (2004) effectivity is a skill of adaptation, level of accomplish goal and success provided from benefits. Level of reaching targeted aims, organizational structure of servicing institution and processes conducting in institution play determinant role in managerial effectiveness of an organization. At this point, organizational culture may affect in service provided. Forming common belief and value system in organizations consisting of individuals in different structures is named as organizational culture. With organizational culture the individuals in organization share some values and are separated from other organizations (Robbins and Judge, 2013). Organizations thought to be effective, have common culture at distinguish point and main function of managerial leadership is to form organizational culture (Hoy and Miskel, 2012). The common values, beliefs and assumptions accepted by the members in the formation of organizational culture are effective (Sökmen, Akkoyunlu and Gayeker, 2017). The components of the organization are effective in the formation of the organizational culture and the members of the organization that will realize these components (Akar, 2017). The importance of organizational culture that universities have in managerial effectiveness in educational service they provide in lifelong learning, can be emphasized in aim, process and organizational structure. 
Universities apart from their various services, are in effort of giving educational service in various ways to all sections of society in lifelong learning field with their continuing education centres.

When we consider that long life learning concept is not on seller's side but on receiver's side and generally adults request education from continuing education centres, it can be said that evaluations of trainees have a particular importance in providing managerial effectiveness of related centres. At this point, necessity of identifying how effective universities conduct long life learning services towards society in the eye of trainees of continuing education centres, forms the aim of research.

The problem sentence of research was determined as follows:

"According to the opinions of trainees what is the level of managerial effectiveness of continuing education centres carrying on its works within the scope of lifelong services at universities?"

Within this scope managerial effectiveness levels of related centres were evaluated according to trainee evaluations received service, were obtained in terms of aim, organizational structure and process dimensions as well as it was obtained if there is any difference according to variables concerning participants of research.

In the direction of obtained problem sentence, the answers of these sub problems were searched:

1. The trainee of continuing education centre;

a. How is his evaluation about these centres in terms of aim dimension?

b. How is his evaluation about these centres in terms of organizational structure dimension?

c. How is his evaluation about these centres in terms of process dimension?

2. According to the gender, age and level of education of trainee;

a. Does his evaluation regarding aim dimension show significant difference?

b. Does his evaluation regarding organizational structure dimension show significant difference?

c. Does his evaluation regarding process dimension show significant difference?

In the research since it was aimed to evaluate managerial effectiveness of educational services conducted in continuing education centres and obtain actual situation of these centres with obtained results, managerial effectiveness concept was held within the scope of lifelong learning concept by considering the aim of continuing education centres and its target population.

\section{Method}

In this section the model, population and sampling of the research, data collection tool, collecting and analysing of data are explained in separate sub titles.

\section{Research Design}

The research was conducted suitable to general survey model in quantitative research model. Although the models frequently used in quantitative researches show a large variation within themselves, it is possible to classify them in general frame under two titles as general survey model and experimental models. General survey models generally try to research and explain a situation or a reality as they are (Şimşek, 2012). In general survey designs the research is conducted by taking the whole of population or a suitable sampling representing population (Karasar, 2012). The number of participant trainees and suitability of evaluation instrument to general survey model was the determiners of using of general survey model in the research.

\section{Population and Sample}

In The target population of research was obtained as continuing education centres conducting their lifelong learning studies within the body of Dokuz Eylül University, Ege University, Eskişehir Osmangazi University and Manisa Celal Bayar University. In forming of research population two factors that are known as special criterions based on researcher, adequacy of opportunity and data collection permission, were effective. All trainees took service from continuing education centres giving lifelong learning service within the body of mentioned universities, took place in population as participants. As sampling regarding research was taken, 179 trainees were reached over 275 trainees that form universe as to compensate 95\% reliable level and 5\% error margin by taking criterions that Şahin (2012) indicated, into consideration. Karasar (2012) defined choosing of participants to represent population by taking their some properties into consideration is named as stratified 
sampling whereas choosing participants randomly is named as simple probability (random) sampling. In the research stratified sampling method was used and in using this method recorded course property was taken into consideration. Later random sampling was followed in related courses. The population and sampling condition belonging to 2016 spring term that the research was done, is given as in Table 1.

Table 1. Trainee numbers showing Population and Sampling condition

\begin{tabular}{llrr}
\hline $\begin{array}{l}\text { Continuing } \\
\text { Centre }\end{array}$ & Education & Population( & Nampling (n) \\
& Name of Course & 26 & 25 \\
& Spanish A1 & 24 & 23 \\
& Spanish A2 & 10 & 6 \\
& German A2 & 12 & 7 \\
DESEM & French & 18 & 5 \\
& Philosophy and Civilization History & 12 & 9 \\
& Speaking English & 14 & 11 \\
& Basic English for Health Personnel & 49 & 23 \\
EGESEM & Conciliation in Legal Disputes & 24 & 19 \\
ESOGÜSEM & English (Upper Int. - YDS) & 13 & 7 \\
& Spanish & 12 & 5 \\
& MYSQL & 11 & 8 \\
MCBÜSEM & General English & 12 & 10 \\
& YDS & 18 & 11 \\
Total & KPSS & 10 & 6 \\
& F Keyboard & 10 & 4 \\
& Persian & 275 & 179 \\
\hline
\end{tabular}

The second sub problem of research was fictionalized on evaluation of problem according to some demographic properties. In this sense some demographic properties belonging to trainees are as they were given in Table 2.

Table 2. Demographic properties of Trainees

\begin{tabular}{rlrlrl}
\hline \multicolumn{2}{c}{ Gender } & \multicolumn{2}{c}{ Education } & \multicolumn{2}{c}{ Age } \\
\hline Property & $\mathrm{n}$ & Property & $\mathrm{n}$ & Property & $\mathrm{n}$ \\
Female & 114 & Secondary ed. & 7 & 20 and below & 20 \\
Male & 65 & Associate deg. & 8 & $21-30$ & 96 \\
& & Undergraduate & 118 & $31-40$ & 38 \\
& & Postgraduate & 46 & $41-50$ & 20 \\
Total & 179 & & & 51 and over & 5 \\
& & Total & 179 & Total & 179 \\
\hline
\end{tabular}

\section{Data Collection Tools}

For data collection in the research "Continuing Education Centre Managerial Effectiveness Data Collection Tool" developed by Y1ldirim (2017) was used. In the section of related data collection tool developed for trainees, 5 point Likert type rating scale was used. In preparation of scale the order of Büyüköztürk (2005) as defining of problem (aim and question), item writing (draft form), asking expert opinion (pre-application form), making pre-application (pre-application - last form of questionnaire) was followed. After defining of problem and writing of scale items, expert opinion was taken and pre-application form was prepared by providing content validity. Pre-application form was presented to evaluation of two Turkish Philology teachers in terms of language and necessary arrangements were done. Then it was obtained that the questions are clear and understandable after the examination of five specialist instructor. In order to control construct validity preapplication stage was followed to make exploratory factor analysis and reliability analysis. Pre-application was done in 2016 spring term MCBÜ Pedagogic Formation Certificate Programme. After pre-application exploratory factor analysis to conduct construct validity by using SPSS 23 programme and reliability test was done for the whole. Exploratory factor analysis was conducted according to principal components analysis by using Varimax 
with Kaiser Normalization method. In deductive analysis done significance level was obtained as $\mathrm{p}<.05$. As $\mathrm{KMO}$ and BTS values belonging to pre-application data were found significant let doing exploratory factor analysis. After pre-application consisting of totally 35 items, 9 items were taken out according to exploratory factor analysis results and 26 items were distributed to aim, organizational structure and process sub dimensions. For 26 items separate reliability tests were done for each item and Cronbach Alpha coefficient was found reliable since it passed .70 value.

\section{Data Collection}

Data collection process was started after giving necessary letter of applications for permission. The data were obtained by printing out developed scale and delivered them to continuing education centre trainees. The trainees in related centres were informed about the aim of research before the training they participated, explained that the results will be used within the scope of research in consideration of confidentiality policy and asked to fill the scale faithfully. Data collection process for each continuing education centre was completed with filling of scales by participants.

\section{Data Analysis}

Within the scope of analysis in order to show distribution of data collected according to the first sub problem, frequency (f) values, present common participant opinions, averages $(\bar{x})$, find criterion distribution and unity of opinion, standard deviation values (s.s.) were calculated and recorded on related tables. During analysis conducted for the second sub problem firstly the aim is to find if total values of items under organizational structure and process dimensions show normal distribution or not. This situation required to use nonparametric tests in analysis of data. In normality test as Kolmogorov Smirnov and Shapiro Wilkisare used, Kolmogorov Smirnov test was taken as basis since the number of participants in this research was over 50 (Bütüner, 2008). In related test results significance level in each aim, organizational structure and process dimensions were found lower than $0.05(\mathrm{p}<.05)$ that showed the absence of normal distribution. Also in evaluations of gender, age and education of trainees in terms of aim, organizational structure and process dimensions the presence of significant difference was examined. With this aim Mann - Whitney U test and Kruskal Wallis test were used. The determinant criterion in Mann - Whitney $U$ test is the presence of two groups in gender independent variable as female and male whereas in Kruskal Wallis test determinant criterion is the presence of more than two groups belonging to each independent variables age and education. The data were analysed by using SPSS 23 (Statistical Package for the Social Science) package programme.

\section{Findings}

In this section obtained findings within the scope of sub problems in the research were given in order.

\section{Findings Regarding First Sub Problem}

Findings obtained from evaluations for related centres in terms of aim, organizational structure and process dimensions according to the trainees of continuing education centres, are as follows:

Trainees of continuing education centres were asked a question consisted of two item in terms of evaluating aim dimension. Trainees mostly stated that their own aims and expectations are considered and in conducted education services there provided contribution in terms of individual, institution and society. Findings obtained as a result of evaluations of trainees regarding aim dimension, are as they were given in Table 3. The findings obtained are similar to those of Ünal, Kalçık and Satuk (2016). The trainees stated that they had the opportunity to realize their goals in these courses, which they participated in for social, economic and individual purposes, and their contributions. Özengi (2017) showed that the aims of the trainee were effective in the education services provided for lifelong learning.

Table 3. Evaluations of Trainees Regarding These Centres in Aim Dimension

\begin{tabular}{lccccccc}
\hline $\begin{array}{l}\text { As determining education services given in } \\
\text { Continuing Education Centres; }\end{array}$ & $\begin{array}{c}\text { None } \\
\text { f }\end{array}$ & $\begin{array}{c}\text { Little } \\
\text { f }\end{array}$ & $\begin{array}{c}\text { Medium } \\
\text { f }\end{array}$ & $\begin{array}{c}\text { Very } \\
\text { f }\end{array}$ & \multicolumn{2}{c}{ Fully } & \multicolumn{2}{c}{$\mathbf{n = 1 7 9}$} & f \\
\hline $\begin{array}{l}\text { I feel the aims of trainees are taken into } \\
\text { consideration. }\end{array}$ & 4 & 11 & 32 & 58 & 74 & 4.04 & 1.021 \\
$\begin{array}{l}\text { I feel providing positive contribution is aimed in } \\
\text { terms of individual, institution or society. }\end{array}$ & 4 & 5 & 33 & 60 & 77 & 4.12 & .958 \\
\hline
\end{tabular}


Trainees of continuing education centres were asked a question consisted of eleven items in terms of evaluating organizational structure dimension. According to evaluations of trainees general average regarding organizational structure was found as 4.14. In this means, trainees mostly stated that present organizational structure is suitable. In terms of present organizational structure the first three statement that had the highest average were like this: With 4.50 average "Education service is given by specialist instructors announced previously", with 4.34 average "Management staff is gentle and reassuring in communication" and with 4.27 average "In order to actualise obtained education programmes necessary opportunities are provided and suitable students are found." The evaluation regarding "Counselling services are given in suitable way" statement has the lowest average with 3.88 point. Findings obtained as a result of evaluations of trainees regarding organizational structure dimension, are as they were given in Table 4. The organizational structure needs to be created in an appropriate manner. However, Taşçı et al. (2015) revealed that there is a significant shortage of human resources in life-long learning institutions. This situation may cause some disruptions in the functioning of the organizational structure.

Table 4. Evaluations of Trainees Regarding These Centres in Organizational Structure Dimension

\begin{tabular}{|c|c|c|c|c|c|c|c|c|}
\hline In continuing education centre; & $\begin{array}{r}\text { None } \\
\mathrm{f}\end{array}$ & $\begin{array}{r}\text { Little } \\
f\end{array}$ & $\begin{array}{r}\text { Medium } \\
\mathrm{f}\end{array}$ & $\begin{array}{r}\text { Very } \\
f\end{array}$ & $\begin{array}{r}\text { Fully } \\
\mathrm{f}\end{array}$ & $\bar{x}$ & s.s. & $\mathbf{n}=\overline{\mathbf{1 7 9}}_{\mathrm{X}}^{\mathrm{avr} .}$ \\
\hline $\begin{array}{l}\text { Counselling services are given in suitable } \\
\text { way. }\end{array}$ & 4 & 15 & 41 & 57 & 62 & 3,88 & 1.051 & \\
\hline $\begin{array}{l}\text { There are understandable signboards } \\
\text { showing units. }\end{array}$ & 4 & 11 & 32 & 62 & 70 & 4,02 & 1.011 & \\
\hline $\begin{array}{l}\text { Pre-enrolment required information is } \\
\text { given. }\end{array}$ & 2 & 8 & 30 & 59 & 80 & 4,16 & .935 & \\
\hline $\begin{array}{l}\text { Official proceedings about trainees are } \\
\text { conducted selectively. }\end{array}$ & 2 & 5 & 30 & 59 & 83 & 4,21 & .897 & \\
\hline $\begin{array}{l}\text { Number of students were registered } \\
\text { avoiding to disturb education. }\end{array}$ & 4 & 8 & 27 & 50 & 90 & 4,20 & 1.000 & \\
\hline $\begin{array}{l}\text { Education service is given by specialist } \\
\text { instructor announced before. }\end{array}$ & 2 & 4 & 16 & 38 & 119 & 4,50 & .837 & $\bar{x}$ \\
\hline $\begin{array}{l}\text { Publicity about present and future } \\
\text { education service is done. }\end{array}$ & 7 & 14 & 37 & 45 & 76 & 3,94 & 1.140 & 4.14 \\
\hline $\begin{array}{l}\text { Demands, suggestions and complaints are } \\
\text { considered. }\end{array}$ & 8 & 11 & 28 & 56 & 76 & 4,01 & 1.112 & \\
\hline $\begin{array}{l}\text { Management personnel is gentle and } \\
\text { reassuring in communication. }\end{array}$ & 2 & 6 & 24 & 45 & 102 & 4,34 & .912 & \\
\hline $\begin{array}{l}\text { Management personnel has an } \\
\text { understanding to support and make lifelong } \\
\text { learning easier. }\end{array}$ & 3 & 7 & 37 & 58 & 74 & 4,08 & .963 & \\
\hline $\begin{array}{l}\text { Necessary opportunities are provided to } \\
\text { achieve obtained education programmes } \\
\text { and find suitable instructors. }\end{array}$ & 2 & 6 & 25 & 54 & 92 & 4,27 & .904 & \\
\hline
\end{tabular}

Trainees of continuing education centres were asked a question consisted of thirteen items in terms of evaluating process dimension. According to evaluations of trainees general average regarding education processes was found as 4.04. Trainees mostly stated that education processes are conducted in a suitable way. From process sub dimensions their evaluation within the context of instruction got 4.04 point, within the context of education services their evaluation got 4.48 whereas within the context of physical structure their evaluation got 3.86 points. In process dimension the first three statement that have the highest average gathered in education services sub dimension. The statements having the highest points were "Education services are conducted according to the period mentioned previously" with 4.56 average, "Education services are conducted according 
to the content mentioned previously" with 4.50 average and "Education services can be flexed according to the demands of trainees" with 4.40 average. The evaluation regarding "Classrooms were decorated suitable to adult liking and standards" statement has the lowest average with 3.47 point and was related to physical structure. Findings obtained as a result of evaluations of trainees regarding process dimension, are as they were given in Table 5. In the light of the findings obtained from this study for lifelong learning services, it is necessary to make improvements in physical facilities. Bulur, Ulas et al. (2018) reached similar findings and emphasized the importance of adult education and the construction of suitable physical spaces.

Table 5. Evaluations of Trainees Regarding These Centres in Process Dimension

\begin{tabular}{|c|c|c|c|c|c|c|c|c|}
\hline \multirow[t]{2}{*}{ In continuing education centre; } & \multirow{2}{*}{$\begin{array}{r}\text { None } \\
\mathrm{f} \\
\end{array}$} & \multirow{2}{*}{$\begin{array}{r}\text { Little } \\
\mathrm{f} \\
\end{array}$} & \multirow{2}{*}{$\begin{array}{r}\text { Medium } \\
\mathrm{f}\end{array}$} & \multirow{2}{*}{$\begin{array}{r}\text { Very } \\
\mathrm{f} \\
\end{array}$} & \multirow{2}{*}{$\begin{array}{r}\text { Fully } \\
\mathrm{f} \\
\end{array}$} & \multicolumn{3}{|c|}{$\begin{array}{c}n=179 \\
\bar{x}_{\text {overall average. }}=4.04\end{array}$} \\
\hline & & & & & & $\bar{x}$ & S.s. & $\overline{\mathbf{X}}_{\mathrm{ort}}$ \\
\hline $\begin{array}{l}\text { The instructor guards functionality in } \\
\text { education starting from subjects and } \\
\text { problems that a trainee expects the } \\
\text { solution most. }\end{array}$ & 2 & 12 & 26 & 58 & 81 & 4.14 & .976 & \\
\hline $\begin{array}{l}\text { The instructor considers the knowledge, } \\
\text { skills and experiences of trainees during } \\
\text { education process. }\end{array}$ & 3 & 13 & 27 & 64 & 72 & 4.06 & .998 & 4.04 \\
\hline $\begin{array}{l}\text { The instructor conducts education process } \\
\text { towards the expectations of a trainee } \\
\text { rather than subject. }\end{array}$ & 5 & 15 & 35 & 58 & 66 & 3.92 & 1.073 & \\
\hline $\begin{array}{l}\text { Education services can be flexed towards } \\
\text { demands of a trainee. }\end{array}$ & 1 & 10 & 23 & 27 & 118 & 4.40 & .951 & $\bar{x}$ \\
\hline $\begin{array}{l}\text { Education services are conducted suitable } \\
\text { to the content mentioned previously. }\end{array}$ & 1 & 4 & 14 & 46 & 114 & 4.50 & .782 & 448 \\
\hline $\begin{array}{l}\text { Education services are conducted suitable } \\
\text { to the period mentioned previously. }\end{array}$ & 2 & 2 & 9 & 47 & 119 & 4.56 & .743 & 4.48 \\
\hline $\begin{array}{l}\text { Physical environment contains elements } \\
\text { thought to belong modern education } \\
\text { understanding. }\end{array}$ & 7 & 12 & 38 & 51 & 71 & 3.93 & 1.110 & \\
\hline $\begin{array}{l}\text { Physical building is psychologically } \\
\text { attractive, reassuring, relaxing and } \\
\text { ordered. } \\
\text { In ordering of education services }\end{array}$ & 10 & 13 & 37 & 55 & 64 & 3.84 & 1.157 & \\
\hline $\begin{array}{l}\text { transportation opportunities were taken } \\
\text { into consideration. }\end{array}$ & 8 & 13 & 38 & 49 & 71 & 3.91 & 1.140 & $\bar{x}$ \\
\hline $\begin{array}{l}\text { In the breaks there are places trainees can } \\
\text { provide their demands. }\end{array}$ & 6 & 10 & 38 & 51 & 74 & 3.99 & 1.076 & 3.86 \\
\hline $\begin{array}{l}\text { In the breaks there are places where } \\
\text { trainees and instructors can share and } \\
\text { communicate easily. }\end{array}$ & 2 & 10 & 27 & 54 & 86 & 4.18 & .963 & \\
\hline $\begin{array}{l}\text { Physical structure of classrooms are big } \\
\text { enough and suitable to given education. }\end{array}$ & 11 & 16 & 45 & 45 & 62 & 3.73 & 1.202 & \\
\hline $\begin{array}{l}\text { Classrooms were decorated suitable to } \\
\text { adult liking and standards }\end{array}$ & 22 & 24 & 31 & 52 & 50 & 3.47 & 1.350 & \\
\hline
\end{tabular}

\section{Findings Regarding Second Sub Problem}

Findings regarding if evaluations continuing education centre trainees show a significant difference according to their gender, age and education in terms of aim, organizational structure and process dimensions, are as follows. In addition, it can be said that the findings are evaluated in terms of the general structure, functioning and problems of educational institutions operating within the scope of lifelong learning and these evaluations are similar to the other studies in which the participants were examined according to the demographic characteristics of the participants (Ünal, 2006; Öner, 2014; Yancar, 2014). Also Kaya (2014) examined the lost social goals of lifelong learning in the historical process taking into account the participant profiles and stated that lifelong learning was commercialized. 
The points continuing education centre trainees got from aim dimension did not show significant difference depending on gender $(\mathrm{U}=3619.5$, $\mathrm{p}>.05)$. This situation can be explained as aim dimension points of female and male trainees are equal. Findings regarding if there is any significant difference according to gender variable in evaluation of trainees regarding aim dimension obtained by Mann Whitney U analysis, were given in Table 6.

Table 6. Mann Whitney U Analysis showing difference regarding points obtained from aim dimension of Trainees Difference Depending on Gender

\begin{tabular}{crrrrr}
\hline Gender & n & Average & Total & U & p \\
\hline Female & 114 & 90.75 & 10345.5 & \multirow{2}{*}{3619.5} & .791 \\
Male & 65 & 88.68 & 5764.5 & & \\
\hline
\end{tabular}

The points that Trainees obtained from aim dimension do not show significant difference depending on age group $\left(\mathrm{X}^{2}=5.517, \mathrm{sd}=4, \mathrm{p}=.238\right)$. This situation can be explained as aim dimension points of trainees in different age groups, are equal. Findings regarding if there is any significant difference according to age variable in evaluation of trainees regarding aim dimension obtained by Kruskal Wallis analysis, were given in Table 7.

Table 7. Kruskal Wallis Analysis showing difference regarding points obtained from aim dimension of Trainees Difference Depending on age group

\begin{tabular}{crrrr}
\hline Age & n & Average & $\mathbf{X}^{\mathbf{2}}$ & sd \\
\hline 20 and below & 20 & 89.33 & & \\
Between 21-30 & 96 & 83.81 & & \\
Between 31-40 & 38 & 96.04 & 5.517 & 4 \\
Between 41-50 & 20 & 99.60 & & .238 \\
51 and over & 5 & 127.30 & & \\
Total & 179 & & & \\
\hline
\end{tabular}

The points that trainees got from aim dimension did not show significant difference depending on education situation $\left(\mathrm{X}^{2}=1.965, \mathrm{sd}=3, \mathrm{p}=.580\right)$. This situation can be explained as aim dimension points of trainees in different education situation. Findings regarding if there is any significant difference according to education variable in evaluation of trainees regarding aim dimension obtained by Kruskal Wallis analysis, were given in Table 8.

Table 8. Kruskal Wallis Analysis showing difference regarding points obtained from aim dimension of Trainees Difference Depending on education

\begin{tabular}{|c|c|c|c|c|c|}
\hline Age & $\mathbf{n}$ & Average & $\mathbf{X}^{2}$ & sd & $\mathbf{p}$ \\
\hline Secondary ed. & 7 & 68.79 & & & \\
\hline Associate degree & 8 & 76.88 & & & \\
\hline Undergraduate & 118 & 91.78 & 1.965 & 3 & .580 \\
\hline Postgraduate & 46 & 90.95 & & & \\
\hline Total & 179 & & & & \\
\hline
\end{tabular}

The points that trainees got from organizational structure dimension did not show significant difference depending on gender $(\mathrm{U}=3703.5, \mathrm{p}>.05)$. This situation can be explained as organizational structure points of male and female trainees are equal. Findings regarding if there is any significant difference according to gender variable in evaluation of trainees regarding organizational structure dimension obtained by Mann Whitney $\mathrm{U}$ analysis, were given in Table 9.

Table 9. Mann Whitney U Analysis showing difference regarding points obtained from organizational structure dimension of Trainees Difference Depending on gender

\begin{tabular}{crrrrr}
\hline Gender & $\mathbf{n}$ & Average & Total & U & p \\
\hline Female & 114 & 10258,50 & 10258.5 & \multirow{2}{*}{3703.5} & \multirow{2}{*}{.996} \\
Male & 65 & 5851,50 & 5851.5 & & \\
\hline
\end{tabular}


The points that trainees got from organizational structure dimension did not show significant difference depending on age group $\left(\mathrm{X}^{2}=7.228, \mathrm{sd}=4, \mathrm{p}=.124\right)$. This situation can be explained as organizational structure points of trainees in different age groups, are equal. Findings regarding if there is any significant difference according to age variable in evaluation of trainees regarding organizational structure dimension obtained by Kruskal Wallis analysis, were given in Table 10.

Table 10. Kruskal Wallis Analysis showing difference regarding points obtained from organizational structure dimension of Trainees Difference Depending on age group

\begin{tabular}{|c|c|c|c|c|c|}
\hline Age & $\mathbf{n}$ & Average & $\mathbf{X}^{2}$ & sd & p \\
\hline 20 and below & 20 & 82,45 & \multirow{6}{*}{7.228} & \multirow{6}{*}{4} & \multirow{6}{*}{.124} \\
\hline Between 21-30 & 96 & 84,38 & & & \\
\hline Between 31-40 & 38 & 95,62 & & & \\
\hline Between 41-50 & 20 & 102,15 & & & \\
\hline 51 and over & 5 & 136,90 & & & \\
\hline Total & 179 & & & & \\
\hline
\end{tabular}

The points that trainees got from organizational structure dimension did not show significant difference depending on education $\left(\mathrm{X}^{2}=1.364, \mathrm{sd}=3, \mathrm{p}=.714\right)$. This situation can be explained as organizational structure points of trainees in different education groups, are equal. Findings regarding if there is any significant difference according to education variable in evaluation of trainees regarding organizational structure dimension obtained by Kruskal Wallis analysis, were given in Table 11.

Table 11. Kruskal Wallis Analysis showing difference regarding points obtained from organizational structure dimension of Trainees Difference Depending on education group

\begin{tabular}{crrrrr}
\hline Age & n & Average & $\mathbf{X}^{\mathbf{2}}$ & sd & $\mathbf{p}$ \\
\hline Secondary school & 7 & 75,36 & & \\
Associate degree & 8 & 80,31 & & 3 & .714 \\
Undergraduate & 118 & 89,41 & 1.364 & & \\
Postgraduate & 46 & 95,42 & & \\
Total & 179 & & & \\
\hline
\end{tabular}

The points that trainees got from process dimension did not show significant difference depending on gender $(\mathrm{U}=3565.5, \mathrm{p}>.05)$. This situation can be explained as process dimension points of male and female trainees are equal. Findings regarding if there is any significant difference according to gender variable in evaluation of trainees regarding process dimension obtained by Mann Whitney $\mathrm{U}$ analysis, were given in Table 12.

Table 12. Mann Whitney U Analysis showing difference regarding points obtained from process dimension of Trainees Difference Depending on gender

\begin{tabular}{crrrrr}
\hline Gender & $\mathbf{n}$ & Average & Total & U & p \\
\hline Female & 114 & 10399,50 & 10399.5 & & \multirow{2}{*}{5675} \\
Male & 65 & 5710,50 & 5710.5 & & .656 .5 \\
\hline
\end{tabular}

The points that trainees got from process dimension did not show significant difference depending on age group $\left(\mathrm{X}^{2}=8.235, \mathrm{sd}=4, \mathrm{p}=.083\right)$. This situation can be explained as process dimension points of trainees in different age group, are equal. Findings regarding if there is any significant difference according to age variable in evaluation of trainees regarding process dimension obtained by Kruskal Wallis analysis, were given in Table 13. 
Table 13. Kruskal Wallis Analysis showing difference regarding points obtained from process dimension of Trainees Difference Depending on age group

\begin{tabular}{|c|c|c|c|c|c|}
\hline Age & $\mathbf{n}$ & Average & $\mathbf{X}^{2}$ & sd & p \\
\hline 20 and below & 20 & 94,03 & \multirow{6}{*}{8.235} & \multirow{6}{*}{4} & \multirow{6}{*}{.083} \\
\hline Between 21-30 & 96 & 82,06 & & & \\
\hline Between 31-40 & 38 & 98,14 & & & \\
\hline Between 41-50 & 20 & 96,18 & & & \\
\hline 51 and over & 5 & 139,80 & & & \\
\hline Total & 179 & & & & \\
\hline
\end{tabular}

The points that trainees got from process dimension did not show significant difference depending on education $\left(\mathrm{X}^{2}=.053, \mathrm{sd}=3, \mathrm{p}=.997\right)$. This situation can be explained as process dimension points of trainees in different education group, are equal. Findings regarding if there is any significant difference according to education variable in evaluation of trainees regarding process dimension obtained by Kruskall Wallis analysis, were given in Table 14

Table 14. Kruskall Wallis Analysis showing difference regarding points obtained from process dimension of Trainees Difference Depending on education group

\begin{tabular}{crrrrr}
\hline Age & n & Average & $\mathbf{X}^{\mathbf{2}}$ & sd & p \\
\hline Secondary school & 7 & 88,79 & & & \\
Associate degree & 8 & 86,25 & .053 & 3 & .997 \\
Undergraduate & 118 & 90,08 & & & \\
Postgraduate & 46 & 90,63 & & & \\
\hline
\end{tabular}

In the second sub-problem, the aim, organizational structure and process dimensions were evaluated according to the variables of gender, age and educational status of the participants and no significant difference was found. In this sense, it can be said that the gender variable does not play a role in the participation targets for the related centres and the gender variable is not determinant in the need for education in the society. Naturally, the expectations of individuals according to gender were similar in organizational structure and process dimension. In addition, according to age and educational status, there was no significant difference in purpose, organizational structure and process dimension. This situation clearly reveals the strengths and weaknesses of the continuous education centres regarding the organizational structure and process dimension.

\section{Discussion and Conclusion}

In this research in which managerial effectiveness of continuing education centres were evaluated according to opinions of trainees, discussion and result sections were conducted over aim, organizational structure and process dimensions.

\section{Aim Dimension}

Trainees stated that their own aims and expectations are considered and in conducted education services there provided contribution in terms of individual, institution and society. In evaluations of trainees for aim dimension, there was not obtained any significant difference according to gender, age and education level.

If it is thought that taking aims of participants into consideration by organization management is important in terms of managerial effectiveness, it can be said that this situation is confirmed by evaluations of trainees. In order to provide acceptance of continuing education centres in society, taking care of related aims of trainees carries an importance. As Argan (2013) expressed responding the needs of target society has positive effect in increasing success and reaching aim. Managers provide participants to reach their aims is accepted as a positive indicator in behalf of manager competence (Armstrong, 2013). Existence of common understanding in educational organizations about printouts of students affect success of students in a positive way (Rollie, 2007). In this sense it can be said that common approaches in aim dimension is shown in continuing education centres provide positive contribution to the success of education programmes accordingly organizational efficiency of institution. Also it can be emphasized that ethical values and services done on behalf of society of organization 
they received service has a role in preference of individuals (Saran et. al., 2011). In this sense during trainings it can be important for trainees to feel this training will make a contribution on behalf of society as well as towards themselves in terms of managerial effectiveness. It is possible for organizations to have many aims supporting its main aim in its activities as well as variety in aims. It is also possible to mention aims such as social, cultural, integration with society besides activities towards economic aims (Argan, 2013). Especially based on evaluations of elder trainees, it can be emphasized that accessing those kind of activities and encountering those kind of opportunities is important. Shortly it can be said that variety of meaningful points and reasons of participants being in organization, increase concern towards organization.

\section{Organizational Structure Dimension}

The evaluations of trainees towards organizational structure of continuing education centres were positive. This situation did not show a significant difference according to gender, age and education of trainees.

In order to reach their aims, it is important for organizations to establish the most suitable organizational structure. Since one of the factors that affect the quality of service is actual organizational structure, it should be solution oriented. As Toprakçı and Akçay (2016) mentioned it is important to establish organizational structure that actualize aims and include assets in hand to organizational structure in the most effective way. Organizations should keep a close watch on changes and consonantly continue their existence (Demirtaş, Özdemir and Küçük, 2016). In this sense, it can be said that profile of trainee receiving education from continuing education centres involves a wide range and education services organized in these centres showing considerable variety, forms a pressure on organizational structure. When lifelong learning is thought, it matters that continuing education centres are more dynamic and in autonomous structure compared to other organized education institutions. Evaluation of trainees obtained in the scope of this research reveals the efficiency of actual organizational structure in continuing education centres. However giving counselling services more effectively, making some activities such as publicity of planned trainings more effective in related organizational structures can be considered important in satisfying expectations and providing managerial effectiveness.

\section{Process Dimension}

Trainees evaluated the process conducted in continuing education centres in positive way within the context of instructor, education services and physical structure. This situation did not show a significant difference according to gender, age and education.

The expectation for participants within the scope of lifelong learning towards received education is like "counsellor beside" instead of "knowledge on stage" (Longworth, 2003). In this sense, it was seen that instructors working in related centres care about experience and priorities of trainees. Organizational managements satisfy educational requirements of trainees during process and making regulations in subjects such as flexibility, programme variety etc. to increase trainee participation as Biçerli (2012) mentioned, can be associated with contribution at efficiency point. Based on evaluations of trainees, it can be said that a specific plan is used in trainings however some flexibilities are also provided towards generated requirements. It is seen that the evaluations done towards physical facilities in process dimension got lower point compared to sub dimensions of instructor and education services. Depending upon developments of period they are in, societies are in effort of developing places regarding education ideally and suitable to aim (Uludağ ve Odac1, 2002). Forming educational settings physically in a way that stimulating participants, supporting aims and making works easier will also bring along successful and effective results (Yıldırım, 2014). In this sense it can be said that places giving education services towards lifelong learning should be modern, reassuring, sufficient for requirements for non-formal and formal education periods, suitable to adult likings and standards, easy for transportation. In order to emphasize economical value of time in hand, starting from physical opportunities should be close to participants as possible (Biçerli, 2012), how other physical opportunities of related institutions affect lifelong learning and adult requirements, can be reviewed within scope of research.

\section{Acknowledgments}

This study was obtained from the doctoral thesis named as "Evaluation of Managerial Effectiveness of Lifelong Learning Services in Universities". In this meaning I want to appreciate to Prof. Dr. R. Cengiz Akçay who is the advisor of this thesis. 


\title{
Sürekli Eğitim Merkezi Kursiyerlerine Göre Yaşam Boyu Öğrenme Hizmetlerinin Yönetsel Etkililiğinin Değerlendirilmesi
}

\begin{abstract}
Giriş
Günümüz bilgi çağına ulaşmamızda insanoğlunun sahip olduğu bilgi ve bu bilgiyi aktarabilme becerisi rol oynamıştır. Bilginin bir kitapta, bir veri bankasında, bir bilgisayar programında sabit durmaması, insan ile somutlaşması, anlam bulması, oluşturulması, çoğaltılması, geliștirilmesi, uygulanması, yorumlanması ve iletilmesi sonucu bilgi toplumuna dönüşüm yolunda insanoğlu merkezde yer almıştır (Drucker, 1993). Eğitimli insan bilgi çağının önemli bir ihtiyacı durumuna gelmiştir.
\end{abstract}

Bilginin edinilmesinde ve aktarılmasında mevcut eğitim örgütlerinin yanı sira onlara alternatif olabilecek düzeydeki çeşitli öğrenme ortamları bilgi çağı ile ortaya çıkmıştır. Tüm bu öğrenme olanaklarının yaşam boyu öğrenme diye bilinen öğrenme ihtiyacını gidermeye yönelik olduğu söylenebilir. Yaşam boyu öğrenme Jarvis'in (2007) belirttiği gibi insanoğlunun tüm yönleriyle edindiği öğrenme süreçleridir. Bireylerin zorunlu eğitimi tamamlamaları, yaşam boyu ve yaşam genişliği kapsamında ihtiyaçları olan tüm öğrenmeleri edinmeleri anlamına gelmemektedir. Çeşitli şekillerde ortaya çıkan sosyal, ekonomik ve bireysel sebepler (Güleç, Çelik ve Demirhan, 2012) yaşam boyu öğrenmeyi zorunlu kılmıştır. Yaşam boyu öğrenme beşikten mezara devam eden bir süreç (MacPhail, 2008) olarak görülebilir.

Çağdaş bir toplum olabilmek ve toplumsal kalkınmayı sağlamak için çağın gerektirdiği bilgi, beceri ve davranışlarla donanmış, yaşam boyu öğrenen bireylere ve yaşam boyu öğrenme hizmeti veren kurumlara olan gereksinim artmaktadır. Yaşam boyu öğrenme sürecinde pek çok öğrenme imkânına erişimin mümkün olduğu günümüz dünyasında üniversitelerin sahip oldukları bilgi birikimi ve olanaklar bakımından önemli rolleri olduğu söylenebilir. Hiçbir şey tarihsel süreç boyunca ilk günkü yapısını muhafaza etmemiş, zaman içerisinde değişim, göstermiştir. Üniversiteler de tarihsel süreç boyunca durağan bir yapıda olmamış, dönemin felsefesine ve ihtiyaçlarına uygun olarak sürekli değişim ve gelişim göstermiş̧tir. Bilimsel araştırma çalışmaları yürütme ve toplum için nitelikli insanlar yetiştirme çabası içinde olan üniversitelerin özelliklerini, ortaya çıkışlarından bu yana üç kategoride toplamak mümkündür. Üniversitelerin tarihsel süreç içerisindeki gelişimi birinci, ikinci ve üçüncü kuşak olarak gerçekleşmiştir (Wissema, 2009). Üniversiteler, uzun yıllar boyunca sadece meslek adamı yetiştirme hedefli mesleki eğitim vermenin dışında pek bir şey yapmamışlardır (Yusuf, 2011). Sanayide rekabetin artması ve artan rekabette ayakta kalabilmek için yenilik ve buluş yapmanın önemli bir çözüm yolu olarak benimsenmesiyle üniversite sanayi işbirliği ihtiyacı ortaya çıkmış ve üniversiteler, yükseköğretim hizmetlerinin yanı sıra $\mathrm{Ar}-\mathrm{Ge}$ çalışmalarına da odaklanmıştır. Mevcut öğretim ve araştırma işlevlerine daha sonra topluma hizmet işlevlerini de ekleyen üniversiteler (Soran, Akkoyunlu ve Kavak, 2006), yaşam boyu öğrenme için önemli kurumlar haline gelmiştir. Bugün üniversitelerin işlevlerini eğitim, araştırma ve topluma hizmet biçiminde üç grupta toplamak mümkündür (Erdem, 2005). Küreselleşmenin artan hızı, gelişmiş ülkelerdeki yaşlanan nüfus ve hızlı teknolojik değişimler (EUA, 2008), yaşam boyu öğrenenler için üniversiteleri harekete geçirmiş ve yaşam boyu öğrenme görevini üniversitelere yüklemiş̧ir. Üniversitelerin toplumdan kopuk olmamaları, toplumla daha fazla iç içe ve topluma daha fazla faydalı olmaları için yaşam boyu öğrenme iyi bir firsat olacaktır. Böylece bilgi toplumunda yaşayan bireyler, üniversiteler aracıllğ̆ ile güvenilir bilgi kaynaklarına ulaşabilecek ve yaşam boyu öğrenmeye devam edeceklerdir.

Tüm örgütsel yapılarda olduğu gibi birer eğitim örgütü olan üniversitelerin de üstlenmiş oldukları görevi yerine getirmiş olması, bu kurumların yönetsel etkililiğini ortaya koymaktadır denilebilir. Arslan (2010) eğitim örgütlerinin daha üretken ve daha başarılı olmalarında yönetsel etkililiklerin önemini vurgulamıştır. Karslı'nın (2004) yaptığı derlemeye göre etkililik; çıktılardan sağlanan başarı, amacı gerçekleştirme düzeyi, gerekli kaynakları kazanma ve çevreye uyum gösterme yeteneğidir. Bir örgütün yönetsel etkililiğinde hizmeti alanların hedeflediği amaçlara ulaşma düzeyi, hizmeti veren kuruma ait örgütsel yapı ve kurumda yürütülen süreçler belirleyici rol oynamaktadır. Bu noktada örgüt kültürünün verilen hizmette etki etmesi söz konusudur. Farklı yapıdaki bireylerden oluşan örgütlerin kendi içinde ortak inanç ve değerler sistemi oluşturmasına örgüt kültürü adı verilir. Örgüt kültürüyle örgütte yer alan bireyler birtakım değerleri paylaşır ve başka örgütlerden ayrılır (Robbins ve Judge, 2013). Etkili olduğu düşünülen örgütler, güçlü ve ayırt edici noktada ortak bir kültürün sahibidir ve yönetsel liderliğin esas işlevi, örgüt kültürünü oluşturmaktır (Hoy ve Miskel, 2012). Örgüt kültürünün oluşumunda üyeler tarafindan kabul edilen ortak değerler, inançlar ve varsayımlar etkilidir (Sökmen, Akkoyunlu ve Gayeker, 2017). Örgüte ait bileşenler örgüt kültürünün oluşumunda etkili olmaktadır ve bu bileşenleri gerçekleştirecek örgüt üyeleridir (Akar, 2017). Üniversitelerin yaşam boyu öğrenme sürecinde 
verdikleri eğitim hizmetlerinde sağlayacakları yönetsel etkililikle ilgili olarak bu anlamda sahip oldukları örgüt kültürünün amaç, süreç ve örgütsel yapı üzerindeki önemi vurgulanabilir.

Üniversiteler yürüttükleri çeşitli hizmetlerin yanı sıra sahip oldukları sürekli eğitim merkezleri ile yaşam boyu öğrenme alanında toplumun her kesimine çeşitli şekillerde eğitim hizmeti verme gayretindedir. Yaşam boyu öğrenme anlayışının satıcıdan yana değil alıcıdan yana olduğu düşünüldüğünde ve sürekli eğitim merkezlerinden genellikle yetişkinlerin eğitim talebinde bulunduğu göz önünde bulundurulduğunda, ilgili merkezlerin yönetsel etkililiği sağlamada bu hizmetleri alan kursiyer değerlendirmelerinin ayrı bir önem taşıdığı söylenebilir. Bu noktada üniversitelerin topluma yönelik yürüttüğü yaşam boyu öğrenme hizmetlerinin sürekli eğitim merkezi kursiyerleri nezdinde ne derece etkili yönetildiğini belirleme ihtiyacı araştırmanın problem durumunu oluşturmuştur.

Araştırmanın problem cümlesi şu şekilde belirlenmiştir:

"Üniversitelerdeki yaşam boyu öğrenme hizmetleri kapsamında çalışmalarını sürdüren sürekli eğitim merkezlerinin yönetsel etkililiği kursiyer görüşlerine göre ne düzeydedir?”

Bu bağlamda bu hizmetleri alan kursiyer değerlendirmelerine göre bu merkezlerin yönetsel etkililik düzeyleri ilgili merkezlerin amaç, örgütsel yapı ve süreç boyutunda belirlenmiş ve araştırmada yer alan katılımcılara ilişsin değişkenlere göre fark olup olmadığı tespit edilmiştir.

Araştırmada belirlenen problem cümlesi doğrultusunda aşağıdaki şu alt problemlere yanıt aranmıştır:

1. Sürekli eğitim merkezi kursiyerlerinin;

a. Amaç boyutunda bu merkezlerle ilgili değerlendirmeleri nasıldır?

b. Örgütsel yapı boyutunda bu merkezlerle ilgili değerlendirmeleri nasıldır?

c. Süreç boyutunda bu merkezlerle ilgili değerlendirmeleri nasıldır?

2. Kursiyerlerin cinsiyetine, yaşına, eğitim durumuna göre;

a. Amaç boyutuna ilişkin değerlendirmeleri anlamlı farklık göstermekte midir?

b. Örgütsel yapı boyutuna ilişkin değerlendirmeleri anlamlı farklık göstermekte midir?

c. Süreç boyutuna ilişkin değerlendirmeleri anlamlı farklık göstermekte midir?

Araştırma ile sürekli eğitim merkezlerinde yürütülen eğitim hizmetlerinin yönetsel etkililiğinin kursiyerlere göre değerlendirilmesi ve elde edilen sonuçlar ile bu merkezlere ait mevcut durumu ortaya çıkarılması amaçlanmış olup; yönetsel etkililik kavramı, sürekli eğitim merkezlerinin amacı ve hedef kitlesi göz önünde bulundurularak yaşam boyu öğrenme kavramı kapsamında ele alınmıştır.

\section{Yöntem}

Bu bölümde araştırmanın modeli, evren ve örneklemi, veri toplama aracı, verilerin toplanması ve verilerin analizi ayrı alt başlıklar halinde açıklanmıştır.

\section{Araştırma Modeli}

Araştırma nicel araştırma türünde tarama modeline uygun olarak yürütülmüştür. Nicel araştırmalarda sıkça kullanılan modeller kendi içinde büyük çeşitlenme göstermekle birlikte, bunlar genel çizgileriyle tarama ve deneme modelleri gibi iki başlık altında sınıflandırmak olanaklıdır. Tarama modelleri genel anlamda var olan durumu veya gerçekliği olduğu haliyle araştırıp açıklamaya çalışmaktadır (Şimşek, 2012). Tarama desenlerinde evrenin tamamı ya da evreni temsil edecek biçimde uygun örneklem alınarak çalışma yürütülür (Karasar, 2012). Araşıtırmada tarama modelinin kullanılmasında araştırma kapsamında yer alan kursiyer sayılarının ve kullanılan ölçme aracının tarama modeline uygun olması belirleyici olmuştur.

\section{Evren ve Örneklem}

Araştırmanın hedef evreni; Dokuz Eylül Üniversitesi, Ege Üniversitesi, Eskişehir Osmangazi Üniversitesi ve Manisa Celal Bayar Üniversitesi bünyesinde yaşam boyu öğrenme çalışmaları yürüten sürekli eğitim merkezleri olarak belirlenmiştir. Araştırma evreninin oluşturulmasında araştırmacı kaynaklı özel ölçütler olarak bilinen 
olanak yeterliliği ve veri toplama izni biçimindeki iki kıstas etkili olmuştur. Belirtilen üniversiteler bünyesinde yaşam boyu öğrenme hizmeti veren sürekli eğitim merkezlerinden hizmet alan tüm kursiyerler araştırmanın katılımcıları olarak evrende yer almıştır. Araştırmaya ilişkin örneklem alınırken Şahin'in (2012) belirttiği ölçütler dikkate alınarak \%95 güven düzeyi ve \%5 hata payı karşılanacak biçimde ana kütleyi oluşturan 275 kursiyer üzerinden toplam 179 kursiyere ulaşılmıştır. Karasar (2012) katılımcıların belirli özelliklerinin dikkate alınarak evreni temsil edebilecek şekilde seçilmesine tabakalı örnekleme; evrenden araştırmaya dâhil edileceklerin rastgele yöntemle seçilmesini basit olasılıklı (rastgele) örnekleme olarak tanımlamaktadır. Araştırmada tabakalı örneklem yöntemi kullanılmış ve bu yöntemin kullanımında kayıtlı olunan kurs özelliği dikkate alınmıştır. Ardından ilgili kurslarda rastgele örnekleme yöntemi izlenmiştir. Araştırmanın yapılmış olduğu 2016 bahar dönemine ait evren ve örneklem durumu Tablo 1'de verildiği gibidir.

Tablo 1. Evren ve Örneklem Durumunu Gösteren Kursiyer Sayıları

\begin{tabular}{llrr}
\hline Sürekli Eğitim Merkezi & Kurs Adı & Evren (N) & Örneklem (n) \\
\hline & İspanyolca A1 & 26 & 25 \\
& İspanyolca A2 & 24 & 23 \\
& Almanca A2 & 10 & 6 \\
& Fransızca & 12 & 7 \\
DESEM & Felsefe ve Uygarlık Tarihi & 18 & 5 \\
& İngilizce Konuşma & 12 & 9 \\
& Sağ. Personeli İçin Temel İngilizce & 14 & 11 \\
& Hukuk Uyuşmazlıklarında Arabuluculuk & 49 & 23 \\
EGESEM & İngilizce (Upper Int. - YDS) & 24 & 19 \\
ESOGÜSEM & İspanyolca & 13 & 7 \\
& MYSQL & 12 & 5 \\
& Genel İngilizce & 11 & 8 \\
MCBÜSEM & YDS & 12 & 10 \\
& KPSS & 18 & 11 \\
Toplam & F Klavye & 10 & 6 \\
\hline
\end{tabular}

Araştırmanın ikinci alt problemi bazı demografik özelliklere göre problem durumunun değerlendirilmesi üzerine kurgulanmıştır. Bu anlamda kursiyerlere ait bazı demografik özellikler Tablo 2'de verildiği biçimde gerçekleşmiştir.

Tablo 2. Kursiyerlere Ait Demografik Özellikler

\begin{tabular}{rlrlllll}
\hline \multicolumn{2}{c}{ Cinsiyet } & \multicolumn{2}{c}{ Yaş } & \multicolumn{2}{c}{ Ĕgitim } \\
\hline Özellik & $\mathrm{n}$ & Özellik & $\mathrm{n}$ & Özellik & $\mathrm{n}$ \\
Kadın & 114 & Ortaöğretim & 7 & 20 ve altı & 20 \\
Erkek & 65 & Önlisans & 8 & $21-30$ & 96 \\
& & Lisans & 118 & $31-40$ & 38 \\
& & Lisansüstü & 46 & $41-50$ & 20
\end{tabular}




\begin{tabular}{|c|c|c|c|c|c|}
\hline & & & & 51 ve üstü & 5 \\
\hline Toplam & 179 & Toplam & 179 & Toplam & 179 \\
\hline
\end{tabular}

\section{Veri Toplama Araçları}

Araştırmada veri toplamak üzere Yıldırım'ın (2017) geliş̧irmiş olduğu "Sürekli Eğitim Merkezi Yönetsel Etkililik Veri Toplama Aracı" kullanılmıştır. İlgili veri toplama aracının kursiyerlere yönelik geliştirilen bölümünde 5'li Likert tipinde derecelendirme ölçeği kullanılmıştır. Ölçeğin hazırlanmasında Büyüköztürk'ün (2005) problemin tanımlanması (amaç ve soru), madde yazılması (taslak form), uzman görüşüne gidilmesi (ön uygulama formu), ön uygulama yapılması (ön uygulama - anketin nihai şekli) biçimindeki sıralaması takip edilmiş̧ir. Araştırma kapsamında problemin tanımlanması ve ölçek maddelerinin yazılmasının ardından uzman görüşü alınmış ve kapsam geçerliliği sağlanarak ön uygulama formu hazırlanmıştır. Hazırlanan ön uygulama formu iki Türk Dili ve Edebiyatı öğretmeninin dil bakımından değerlendirmelerine sunulmuş ve gerekli düzenlemeler yapılmıştır. Ardından uzman beş öğretim elemanı tarafindan maddelerin incelenmesiyle soruların açık ve anlaşılır olduğu belirlenmiştir. Daha sonra yapı geçerliliğini kontrol etmek için; açımlayıcı faktör analizi ve güvenirlik analizi yapmak üzere ön uygulama aşamasına geçilmiştir. Ön uygulama 2016 Bahar dönemi MCBÜ_Pedagojik Formasyon Sertifika Programında gerçekleştirilmiştir. Ön uygulamanın ardından SPSS 23 programı kullanılarak yapı geçerliliği çalışmasını yürütmek üzere açımlayıcı faktör analizi (exploratory factor analysis) ve bütün için güvenirlik testi (reliability test) yapılmıştır. Açımlayıcı faktör analizi varimax dik döndürme yöntemi kullanılarak temel bileşenler analizine göre (principal components analysis) yürütülmüştür. Yapılan çıkarımsal analizlerde anlamlılık düzeyi $p<.05$ olarak belirlenmiş̧ir. Ön uygulama verilerine ait KMO ve BTS değerlerinin anlamlı çıkması, açımlayııı faktör analizi yapılmasına izin vermiştir. Toplam 35 madde ile gidilen ön uygulama sonrasında açımlayıcı faktör analizi sonuçlarına göre 9 madde ölçme aracından atılmış ve 26 madde amaç, örgütsel yapı ve süreç biçimindeki alt boyutlara göre dağılım göstermiştir. Ardından kalan 26 maddeye yönelik bütün için ve her bir faktör için ayrı ayrı güvenirlik testleri yapılmış ve Cronbach Alpha iç tutarlılık katsayıları .70 değerini geçerek güvenilir bulunmuştur.

\section{Verilerin Toplanması}

Veri toplama sürecine gerekli izin başvurularının yapılmasının ardından başlanmıştır. Veriler, geliştirilmiş olan ölçeğin basılı forma dönüştürülmesi ve örneklemi oluşturun sürekli eğitim merkezi kursiyerlerine dağıtılması ile elde edilmiştir. İlgili merkezlerdeki kursiyerlerin katıldıkları eğitimler öncesi kendilerine araştırmanın amacı hakkında bilgi verilmiş, kendilerine gizlilik ilkeleri gözetilerek sonuçların araştırma kapsamında kullanılacağı açıklanmış ve kendilerinden içtenlikle ölçeği doldurmaları temenni edilmiştir. Katılımcıların verilen ölçekleri doldurması ile veri toplama süreci her bir sürekli eğitim merkezi için tamamlanmış olmuştur.

\section{Verilerin Analizi}

Araştırma kapsamında birinci alt probleme göre toplanan verilerin analizinde veri dağılımını göstermek için frekans (f) değerleri, katılımcı ortak görüşlerini sunmak için ortalamalar $(\overline{\mathrm{x}})$, ölçüt dağıllımı ve görüş birlik düzeylerini bulmak için standart sapma (s.s.) değerleri hesaplanarak ilgili tablolara işlenmiştir. İkinci alt probleme yönelik yürütülen analiz sürecinde ilk olarak amaç, örgütsel yapı ve süreç biçimindeki boyutlar altında yer alan maddelerin toplam değerlerinin normal dağılım göstermediği tespit edilmiştir. Bu durum verilerin analizinde nonparametrik testlerin kullanımını gerektirmiştir. Normalik testlerinde Kolmogorov Smirnov ve Shapiro Wilkis testleri kullanılmakta olup, bu araştırmada yer alan katılımcı sayısı 50'den fazla olduğu için (Bütüner, 2008) Kolmogorov Smirnov testi temel alınmıştır. İlgili test sonuçlarında amaç, örgütsel yapı ve süreç boyutlarının her birinde anlamlılık düzeyi 0.05 'ten küçük $(\mathrm{p}<.05)$ çıkmış ve normal dağılım olmadığı görülmüştür. Kursiyerlere ait cinsiyet, yaş ve eğitim durumu biçimindeki özelliklere göre amaç, örgütsel yapı ve süreç boyutlarına ilişkin değerlendirmelerde anlamlı bir fark olup olmadığı incelenmiştir. Bu amaçla Mann Whitney U testine ve Kruskal Wallis testine başvurulmuştur. Mann - Whitney U testinin yapılmasında belirleyici ölçüt, cinsiyet bağımsız değişkeninde kadın ve erkek biçiminde iki grubun olması; Kruskal Wallis testinin yapılmasında belirleyici ölçüt, yaş ve eğitim durumu şeklindeki bağımsız değişkenlerin her birine ait grup sayılarının ikiden fazla olmasidır. Veriler, SPSS 23 (Statistical Package for the Social Science) paket programı kullanılarak çözümlenmiştir. 


\section{Bulgular}

$\mathrm{Bu}$ bölümde araştırmada yer alan alt problemler kapsamında elde edilen bulgular sıralı bir biçimde sunulmuştur.

\section{Birinci Alt Probleme İlişkin Bulgular}

Sürekli eğitim merkezi kursiyerlerine göre amaç, örgütsel yapı ve süreç boyutlarında ilgili merkezlere yönelik değerlendirmeler sonucu elde edilen bulgular şu şekildedir.

Sürekli eğitim merkezi kursiyerlerine amaç boyutunu değerlendirmeleri bakımından iki maddelik soru yöneltilmiştir. Kursiyerler; kendi amaç ve beklentilerinin dikkate alındığını ve yürütülen eğitim hizmetlerinde birey, kurum veya toplum bakımından katkı sağlandığını ağırlıklı olarak ifade etmişlerdir. Kursiyerlerin amaç boyutuna ilişkin değerlendirmeleri sonucu elde edilen bulgular Tablo 3'de gösterildiği biçimdedir. Elde edilen bulgular Ünal, Kalçık ve Satuk'un (2016) çalışması ile benzerlik göstermektedir denilebilir. Kursiyerler sosyal, ekonomik ve bireysel amaçlarla katıldıkları bu kurslarda kendi amaçlarını gerçekleştirme olanağı bulduklarını ve bu durumun sağladığı katkıları ifade etmişlerdir. Özengi (2017) yaşam boyu öğrenmeye yönelik verilen eğitim hizmetlerinde kursiyer amaçlarının etkili olduğunu yaptığı çalışma ile ortaya koymuştur.

Tablo 3. Kursiyerlerin Amaç Boyutunda Bu Merkezlerle İlgili Değerlendirmeleri

\begin{tabular}{|c|c|c|c|c|c|c|c|}
\hline \multirow{2}{*}{$\begin{array}{l}\text { Sürekli eğitim merkezinde verilen eğitim } \\
\text { hizmetleri belirlenirken; }\end{array}$} & \multirow{2}{*}{$\begin{array}{c}\text { Hiç } \\
\mathrm{f}\end{array}$} & \multirow{2}{*}{$\begin{array}{c}\mathrm{Az} \\
\mathrm{f}\end{array}$} & \multirow{2}{*}{$\begin{array}{c}\text { Orta } \\
\mathrm{f}\end{array}$} & \multirow{2}{*}{$\begin{array}{c}\text { Çok } \\
\mathrm{f}\end{array}$} & \multirow{2}{*}{$\begin{array}{c}\text { Tam } \\
\mathrm{f}\end{array}$} & \multicolumn{2}{|c|}{$\mathbf{n}=179$} \\
\hline & & & & & & $\bar{x}$ & s.s. \\
\hline Kursiyer amaçlarının dikkate alındığını hissediyorum. & 4 & 11 & 32 & 58 & 74 & 4.04 & 1.021 \\
\hline $\begin{array}{l}\text { Birey, kurum veya toplum bakımından olumlu katkı } \\
\text { sağlamanın amaçlandığını hissediyorum. }\end{array}$ & 4 & 5 & 33 & 60 & 77 & 4.12 & .958 \\
\hline
\end{tabular}

Sürekli eğitim merkezi kursiyerlerine örgütsel yapı boyutunu değerlendirmeleri bakımından on bir maddelik soru yöneltilmiştir. Kursiyer değerlendirmelerine göre örgütsel yapıya ilişsin genel ortalama 4.14 olarak gerçekleşmiştir. Bu anlamda kursiyerler mevcut örgütsel yapının uygun olduğunu ağırlıklı olarak ifade etmişlerdir. Mevcut örgütsel yapı kapsamında en yüksek ortalamaya sahip ilk üç ifade: 4.50 ortalama ile "Eğitim hizmetini önceden duyurulan uzman öğretim elemanı vermektedir", 4.34 ortalama ile "İdari personel iletişimde nazik ve güven vericidir" ve 4.27 ortalama ile "Belirlenen eğitim programlarını gerçekleştirmek için gerekli imkânlar sağlanmakta ve uygun öğreticiler bulunmaktadır" biçimindedir. "Danışma hizmetleri uygun biçimde verilmektedir" ifadesine ilişkin değerlendirme 3.88 puan ile en düşük ortalamaya sahiptir. Kursiyerlerin örgütsel yapı boyutuna ilişkin değerlendirmeleri sonucu elde edilen bulgular Tablo 4'de gösterildiği biçimdedir. Örgütsel yapının amaca uygun bir biçimde oluşturulması gerekmektedir. Ancak Taşçı ve diğ . (2015) ortaya koyduğu gibi yaşam boyu öğrenme hizmeti veren kurumlarda önemli ölçüde insan kaynağı sıkıntısı yaşanmaktadır. Bu durum örgütsel yapının işleyişinde bazı aksaklıklara neden olmaktadır denilebilir.

Tablo 4. Kursiyerlerin Örgütsel Yapı Boyutunda Bu Merkezlerle İlgili Değerlendirmeleri

\begin{tabular}{|c|c|c|c|c|c|c|c|c|}
\hline \multirow{2}{*}{ Sürekli eğitim merkezinde; } & \multirow{2}{*}{$\begin{array}{r}\text { Hiç } \\
\mathrm{f} \\
\end{array}$} & \multirow{2}{*}{$\begin{array}{r}\mathbf{A z} \\
\mathrm{f} \\
\end{array}$} & \multirow{2}{*}{$\begin{array}{r}\text { Orta } \\
\mathrm{f} \\
\end{array}$} & \multirow{2}{*}{$\begin{array}{r}\text { Çok } \\
\mathrm{f} \\
\end{array}$} & \multirow{2}{*}{$\begin{array}{r}\text { Tam } \\
F \\
\end{array}$} & \multicolumn{3}{|c|}{$\mathbf{n}=\mathbf{1 7 9}$} \\
\hline & & & & & & $\bar{x}$ & s.s. & $\overline{\mathbf{X}}_{\text {ort }}$ \\
\hline Danışma hizmetleri uygun biçimde verilmektedir. & 4 & 15 & 41 & 57 & 62 & 3,88 & 1.051 & \\
\hline Birimleri gösteren anlaşılır tabelalar vardır. & 4 & 11 & 32 & 62 & 70 & 4,02 & 1.011 & \\
\hline Kayıt öncesi ihtiyaç duyulan bilgiler verilmektedir. & 2 & 8 & 30 & 59 & 80 & 4,16 & .935 & \\
\hline Kursiyerlerle ilgili resmi işlemler titizlikle yürütülmektedir. & 2 & 5 & 30 & 59 & 83 & 4,21 & .897 & $\bar{x}$ \\
\hline Öğretim işini aksatmayacak sayıda öğrenci kaydedilmiştir. & 4 & 8 & 27 & 50 & 90 & 4,20 & 1.000 & 4.14 \\
\hline $\begin{array}{l}\text { Eğitim hizmetini önceden duyurulan uzman öğretim elemanı } \\
\text { vermektedir. }\end{array}$ & 2 & 4 & 16 & 38 & 119 & 4,50 & .837 & \\
\hline $\begin{array}{l}\text { Mevcut ve ileride verilmesi planlanan eğitim hizmetleri ile } \\
\text { ilgili tanıtımlar yapılmaktadır. }\end{array}$ & 7 & 14 & 37 & 45 & 76 & 3,94 & 1.140 & \\
\hline İstek, öneri ve şikâyetlerle ilgilenilmektedir. & 8 & 11 & 28 & 56 & 76 & 4,01 & 1.112 & \\
\hline
\end{tabular}


İdari personel iletişimde nazik ve güven vericidir.

İdari personel yaşam boyu öğrenmeyi destekleyici ve

kolaylaştırıcı bir anlayışa sahiptir.

Belirlenen eğitim programlarını gerçekleştirmek için gerekli imkânlar sağlanmakta ve uygun öğreticiler bulunmaktadır.

$\begin{array}{rrrrrrr}2 & 6 & 24 & 45 & 102 & 4,34 & .912 \\ 3 & 7 & 37 & 58 & 74 & 4,08 & .963 \\ 2 & 6 & 25 & 54 & 92 & 4,27 & .904\end{array}$

Sürekli eğitim merkezi kursiyerlerine süreç boyutunu değerlendirmeleri bakımından on üç maddelik soru yöneltilmiştir. Eğitim süreçlerinin kursiyer değerlendirme düzeyine ilişkin genel ortalama 4.04 olarak gerçekleşmiştir. Kursiyerler eğitim süreçlerinin uygun biçimde yürütüldüğünü ağırlıklı olarak ifade etmişlerdir. Süreç alt boyutlarından öğretim elemanı bağlamında değerlendirmeleri 4.04 - eğitim hizmetleri bağlamında değerlendirmeleri 4.48 - fiziki yapı bağlamında değerlendirmeleri 3.86 puan almıştır. Süreç boyutunda en yüksek ortalamaya sahip ilk üç ifade eğitim hizmetleri alt boyutunda toplanmıştır. En yüksek puan alan ifadeler; 4.56 ortalama ile "Eğitim hizmetleri önceden belirtilen süreye uygun olarak yürütülmektedir", 4.50 ortalama ile "Eğitim hizmetleri önceden belirtilen içeriğe uygun olarak yürütülmektedir" ve 4.40 ortalama ile "Eğitim hizmetleri kursiyer ihtiyaçlarına yönelik esnetilebilmektedir" biçimindedir. "Derslikler yetişkin zevk ve ölçütlerine uygun dekore edilmiştir" ifadesine ilişkin değerlendirme 3.47 puan ile en düşük ortalamaya sahip olup, fiziki yapı ile ilgilidir. Kursiyerlerin süreç boyutuna ilişkin değerlendirmeleri sonucu elde edilen bulgular Tablo 5'te gösterildiği biçimdedir. Yaşam boyu öğrenme hizmetlerine yönelik bu çalışma ile elde edilen bulgular 1şı̆̆ında fiziki olanaklar konusunda iyileştirmelerin yapılması gereklidir denilebilir. Benzer bulgulara Bulur, Ulaş ve diğ. (2018) ulaşmış olup, yetişkin eğitiminin önemsenmesi ve amaca uygun fiziki mekânların inşa edilmesi vurgulanmıştır.

Tablo 5. Kursiyerlerin Süreç Boyutunda Bu Merkezlerle İlgili Değerlendirmeleri

\begin{tabular}{|c|c|c|c|c|c|c|c|c|}
\hline Sürekli eğitim merkezinde; & $\begin{array}{r}\text { Hiç } \\
\mathrm{f}\end{array}$ & $\begin{array}{r}\mathrm{Az} \\
\mathrm{f}\end{array}$ & $\begin{array}{r}\text { Orta } \\
\mathrm{f}\end{array}$ & $\begin{array}{r}\text { Çok } \\
\mathrm{f}\end{array}$ & $\begin{array}{r}\text { Tam } \\
\mathrm{f}\end{array}$ & $\frac{n}{x}$ & $\begin{array}{l}\overline{\bar{X}} \text { genel o } \\
\text { S.S. }\end{array}$ & $=\frac{4.04}{X_{\text {ort }}}$ \\
\hline \multicolumn{9}{|l|}{ Öğretim elemanı kursiyerin en çok çözüm beklediği } \\
\hline $\begin{array}{l}\text { konulardan ve problemlerden başlayarak eğitimde } \\
\text { işlevsellik gözetmektedir. }\end{array}$ & 2 & 12 & 26 & 58 & 81 & 4.14 & .976 & \multirow{4}{*}{4.04} \\
\hline Öğretim elemanı öğretim sürecinde kursiyerlerin & & & & & & & & \\
\hline kendi bilgi, beceri ve tecrübeleri dikkate almaktadır. & 3 & 13 & 27 & 64 & 72 & 4.06 & .998 & \\
\hline $\begin{array}{l}\text { Öğretim elemanı eğitim sürecini konudan ziyade } \\
\text { kursiyer beklentilerine yönelik yürütmektedir. }\end{array}$ & 5 & 15 & 35 & 58 & 66 & 3.92 & 1.073 & \\
\hline $\begin{array}{l}\text { Eğitim hizmetleri kursiyer ihtiyaçlarına yönelik } \\
\text { esnetilebilmektedir. }\end{array}$ & 1 & 10 & 23 & 27 & 118 & 4.40 & .951 & \multirow{3}{*}{$\bar{x}$} \\
\hline $\begin{array}{l}\text { Eğitim hizmetleri önceden belirtilen içeriğe uygun } \\
\text { olarak yürütülmektedir. }\end{array}$ & 1 & 4 & 14 & 46 & 114 & 4.50 & .782 & \\
\hline $\begin{array}{l}\text { Eğitim hizmetleri önceden belirtilen süreye uygun } \\
\text { olarak yürütülmektedir. }\end{array}$ & 2 & 2 & 9 & 47 & 119 & 4.56 & .743 & \\
\hline $\begin{array}{l}\text { Fiziki ortam çağdaş eğitim anlayışına ait olduğu } \\
\text { düşünülen öğeler barındırmaktadır. }\end{array}$ & 7 & 12 & 38 & 51 & 71 & 3.93 & 1.110 & \multirow{8}{*}{3.86} \\
\hline $\begin{array}{l}\text { Fiziki yapı psikolojik olarak çekici, güven verici, } \\
\text { rahatlatıcı ve düzenlidir. }\end{array}$ & 10 & 13 & 37 & 55 & 64 & 3.84 & 1.157 & \\
\hline $\begin{array}{l}\text { Eğitim hizmetlerinin düzenlenmesinde ulaşım } \\
\text { olanakları dikkate alınmıştır. }\end{array}$ & 8 & 13 & 38 & 49 & 71 & 3.91 & 1.140 & \\
\hline $\begin{array}{l}\text { Eğitim aralarında kursiyerlerin ihtiyaçlarını } \\
\text { karşılayabileceği mekânlar vardır. }\end{array}$ & 6 & 10 & 38 & 51 & 74 & 3.99 & 1.076 & \\
\hline Eğitim aralarında kursiyerlerin ve öğretim & & & & & & & & \\
\hline $\begin{array}{l}\text { elemanlarının rahatlıkla iletişim ve paylaşımda } \\
\text { bulunabileceği mekânlar vardır. }\end{array}$ & 2 & 10 & 27 & 54 & 86 & 4.18 & .963 & \\
\hline $\begin{array}{l}\text { Dersliklerin fiziki yapısı yeterli büyüklükte ve verilen } \\
\text { eğitime uygundur. }\end{array}$ & 11 & 16 & 45 & 45 & 62 & 3.73 & 1.202 & \\
\hline $\begin{array}{l}\text { Derslikler yetişkin zevk ve ölçütlerine uygun dekore } \\
\text { edilmiştir. }\end{array}$ & 22 & 24 & 31 & 52 & 50 & 3.47 & 1.350 & \\
\hline
\end{tabular}

\section{İkinci Alt Probleme İlişkin Bulgular}

Sürekli eğitim merkezi kursiyerlerinin cinsiyetine, yaşına ve eğitim durumuna göre amaç, örgütsel yapı ve süreç boyutları bakımından yapmış oldukları değerlendirmelerin anlamlı farklılık gösterip göstermediğine ilişkin elde edilen bulgular şu şekildedir. Ayrıca elde edilen bulguların yaşam boyu öğrenme kapsamında faaliyet 
gösteren eğitim kurumlarının genel yapısı, işleyişi ve sorunları bakımından değerlendirildiği ve bu değerlendirmelerin katılımcıların demografik özelliklerine göre incelendiği diğer araştırmalarla benzerlik gösterdiği söylenebilir (Ünal, 2006; Öner, 2014; Yancar, 2014). Kaya (2014) ise yaşam boyu öğrenmenin kaybolan sosyal amaçlarını katılımcı profillerini de dikkate alarak tarihsel süreçte incelemiş ve yaşam boyu öğrenmenin ticarileştiğini belirtmiştir.

Sürekli eğitim merkezi kursiyerlerinin, amaç boyutundan almış oldukları puanlar cinsiyete bağlı olarak anlamlı farklılık göstermemektedir ( $\mathrm{U}=3619.5, \mathrm{p}>.05)$. Bu durum, kadın ve erkek kursiyerlerin amaç boyutu puanları eşittir şeklinde de açıklanabilir. Mann Whitney U analizi kullanılarak kursiyerlerin amaç boyutuna ilişkin değerlendirmelerinde cinsiyet değişkenine göre anlamlı bir fark olup olmadığına dair bulgulara Tablo 6 'da görüldüğü biçimde ulaşılmıştır.

Tablo 6. Kursiyerlerin Amaç Boyutundan Aldıkları Puanların Cinsiyete Bağlı Olarak Farklılığını Gösteren Mann Whitney U Analizi

\begin{tabular}{crrrrr}
\hline Cinsiyet & $\mathbf{n}$ & Sıra Ortalaması & Sıra Toplamı & U & p \\
\hline Kadın & 114 & 90.75 & 10345.5 & \multirow{2}{*}{3619.5} & \multirow{2}{*}{791} \\
Erkek & 65 & 88.68 & 5764.5 & & \\
\hline
\end{tabular}

Sürekli eğitim merkezi kursiyerlerinin, amaç boyutundan almış oldukları puanlar yaş grubuna bağlı olarak anlamlı farklılık göstermemektedir $\left(X^{2}=5.517, \mathrm{sd}=4, \mathrm{p}=.238\right)$. Bu durum, farklı yaş grubundaki kursiyerlerin amaç boyutu puanları eşittir şeklinde de açıklanabilir. Kruskal Wallis analizi kullanılarak kursiyerlerin amaç boyutuna ilişkin değerlendirmelerinde yaş değişkenine göre anlamlı bir fark olup olmadığına dair bulgulara Tablo 7'de görüldüğü biçimde ulaşılmıştır.

Tablo 7. Kursiyerlerin Amaç Boyutundan Aldıkları Puanların Yaş Grubuna Bağlı Olarak Farklılığını Gösteren Kruskal Wallis Analizi

\begin{tabular}{|c|c|c|c|c|c|}
\hline Yaş & $\mathbf{n}$ & Sira Ort. & $\mathbf{X}^{2}$ & sd & $\mathbf{p}$ \\
\hline 20 ve alt1 & 20 & 89.33 & \multirow{6}{*}{5.517} & \multirow{6}{*}{4} & \multirow{6}{*}{.238} \\
\hline $21-30$ aras1 & 96 & 83.81 & & & \\
\hline $31-40$ aras 1 & 38 & 96.04 & & & \\
\hline $41-50$ aras 1 & 20 & 99.60 & & & \\
\hline 51 ve üstü & 5 & 127.30 & & & \\
\hline Toplam & 179 & & & & \\
\hline
\end{tabular}

Sürekli eğitim merkezi kursiyerlerinin, amaç boyutundan almış oldukları puanlar eğitim durumu grubuna bağlı olarak anlamlı farklılık göstermemektedir $\left(\mathrm{X}^{2}=1.965, \mathrm{sd}=3, \mathrm{p}=.580\right)$. Bu durum, farklı eğitim durumu grubundaki kursiyerlerin amaç boyutu puanları eşittir şeklinde de açıklanabilir. Kruskal Wallis analizi kullanılarak kursiyerlerin amaç boyutuna ilişkin değerlendirmelerinde eğitim durumu değişkenine göre anlamlı bir fark olup olmadığına dair bulgulara Tablo 8'de görüldüğü biçimde ulaşılmıştır.

Tablo 8. Kursiyerlerin Amaç Boyutundan Aldıkları Puanların Eğitim Durumu Grubuna Bağlı Olarak Farklılığını Gösteren Kruskal Wallis Analizi

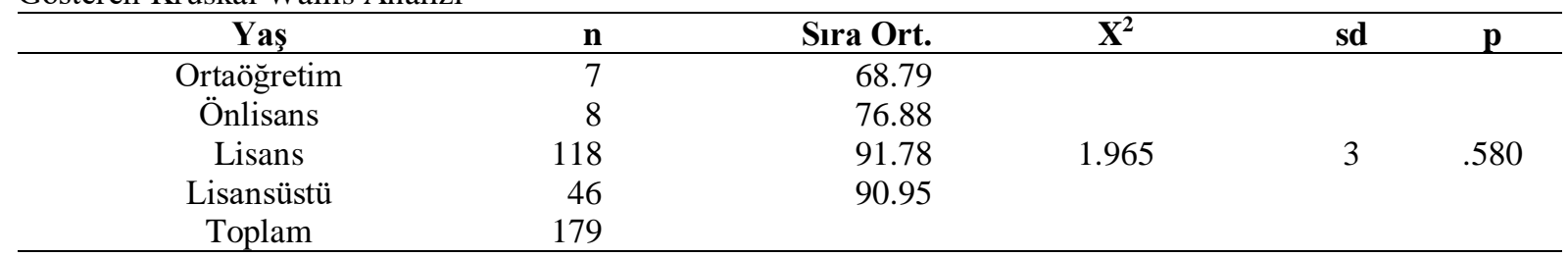

Sürekli eğitim merkezi kursiyerlerinin, örgütsel yapı boyutundan almış oldukları puanlar cinsiyete bağlı olarak anlamlı farklılık göstermemektedir (U=3703.5, p>.05). Bu durum, kadın ve erkek kursiyerlerin örgütsel yapı boyutu puanları eşittir şeklinde de açıklanabilir. Mann Whitney U analizi kullanılarak kursiyerlerin örgütsel yapı boyutuna ilişkin değerlendirmelerinde cinsiyet değişkenine göre anlamlı bir fark olup olmadığına dair bulgulara Tablo 9'da görüldüğü biçimde ulaşılmıştır. 
Tablo 9. Kursiyerlerin Örgütsel Yapı Boyutundan Aldıkları Puanların Cinsiyete Bağlı Olarak Farklılığını Gösteren Mann Whitney U Analizi

\begin{tabular}{crrrrc}
\hline Cinsiyet & n & Sira Ortalaması & Sıra Toplamı & U & p \\
\hline Kadın & 114 & 10258,50 & 10258.5 & 3703.5 & .996 \\
Erkek & 65 & 5851,50 & 5851.5 & & \\
\hline
\end{tabular}

Sürekli eğitim merkezi kursiyerlerinin, örgütsel yapı boyutundan almış oldukları puanlar yaş grubuna bağlı olarak anlamlı farklılık göstermemektedir $\left(\mathrm{X}^{2}=7.228, \mathrm{sd}=4, \mathrm{p}=.124\right) . \mathrm{Bu}$ durum, farklı yaş grubundaki kursiyerlerin örgütsel yapı boyutu puanları eşittir şeklinde de açıklanabilir. Kruskal Wallis analizi kullanılarak kursiyerlerin örgütsel yapı boyutuna ilişkin değerlendirmelerinde yaş değişkenine göre anlamlı bir fark olup olmadığına dair bulgulara Tablo 10'da görüldüğü biçimde ulaşılmıştır.

Tablo 10. Kursiyerlerin Örgütsel Yapı Boyutundan Aldıkları Puanların Yaş Grubuna Bağlı Olarak Farklılığını Gösteren Kruskal Wallis Analizi

\begin{tabular}{crrrrr}
\hline Yaş & n & Sira Ort. & $\mathbf{X}^{\mathbf{2}}$ & sd & p \\
\hline 20 ve altı & 20 & 82,45 & & & \\
$21-30$ aras1 & 96 & 84,38 & & & \\
$31-40$ aras1 & 38 & 95,62 & 7.228 & 4 & .124 \\
$41-50$ aras1 & 20 & 102,15 & & & \\
51 ve üstü & 5 & 136,90 & & & \\
Toplam & 179 & & & & \\
\hline
\end{tabular}

Sürekli eğitim merkezi kursiyerlerinin, örgütsel yapı boyutundan almış oldukları puanlar eğitim durumu grubuna bağlı olarak anlamlı farklılık göstermemektedir $\left(X^{2}=1.364\right.$, sd=3, p=.714). Bu durum, farklı eğitim durumu grubundaki kursiyerlerin örgütsel yapı boyutu puanları eşittir şeklinde de açıklanabilir. Kruskall Wallis analizi kullanılarak kursiyerlerin örgütsel yapı boyutuna ilişkin değerlendirmelerinde eğitim durumu değişkenine göre anlamlı bir fark olup olmadığına dair bulgulara Tablo 11'de görüldüğü biçimde ulaşılmıştır.

Tablo 11. Kursiyerlerin Örgütsel Yapı Boyutundan Aldıkları Puanların Eğitim Durumu Grubuna Bağı Olarak Farklılı̆̆ını Gösteren Kruskal Wallis Analizi

\begin{tabular}{crrrrr}
\hline Yaş & $\mathbf{n}$ & Sira Ort. & $\mathbf{X}^{\mathbf{2}}$ & sd & $\mathbf{p}$ \\
\hline Ortaöğretim & 7 & 75,36 & & & \\
Önlisans & 8 & 80,31 & & & \\
Lisans & 118 & 89,41 & 1.364 & 3 & .714 \\
Lisansüstü & 46 & 95,42 & & & \\
Toplam & 179 & & & & \\
\hline
\end{tabular}

Sürekli eğitim merkezi kursiyerlerinin, süreç boyutundan almış oldukları puanlar cinsiyete bağlı olarak anlamlı farklılık göstermemektedir $(\mathrm{U}=3565.5, \mathrm{p}>.05)$. Bu durum, kadın ve erkek kursiyerlerin süreç boyutu puanları eşittir şeklinde de açıklanabilir. Mann Whitney U analizi kullanılarak kursiyerlerin süreç boyutuna ilişskin değerlendirmelerinde cinsiyet değişkenine göre anlamlı bir fark olup olmadığına dair bulgulara Tablo 12 'de görüldü̆ğü biçimde ulaşılmıştır.

Tablo 12. Kursiyerlerin Süreç Boyutundan Aldıkları Puanların Cinsiyete Bağlı Olarak Farklı1ığını Gösteren Mann Whitney U Analizi

\begin{tabular}{crrrrc}
\hline Cinsiyet & n & Sira Ortalaması & Sira Toplamı & U & p \\
\hline Kadın & 114 & 10399,50 & 10399.5 & \multirow{2}{*}{ (5565.5 } & .675 \\
Erkek & 65 & 5710,50 & 5710.5 & & \\
\hline
\end{tabular}

Sürekli eğitim merkezi kursiyerlerinin, süreç boyutundan almış oldukları puanlar yaş grubuna bağlı olarak anlamlı farklılık göstermemektedir $\left(\mathrm{X}^{2}=8.235, \mathrm{sd}=4, \mathrm{p}=.083\right)$. Bu durum, farklı yaş grubundaki kursiyerlerin 
süreç boyutu puanları eşittir şeklinde de açıklanabilir. Kruskal Wallis analizi kullanılarak kursiyerlerin süreç boyutuna ilişkin değerlendirmelerinde yaş değişkenine göre anlamlı bir fark olup olmadığına dair bulgulara Tablo 13'de görüldüğü biçimde ulaşılmıştır.

Tablo 13. Kursiyerlerin Süreç Boyutundan Aldıkları Puanların Yaş Grubuna Bağlı Olarak Farklılığını Gösteren Kruskal Wallis Analizi

\begin{tabular}{crrrrr}
\hline Yaş & $\mathbf{n}$ & Sıra Ort. & $\mathbf{X}^{\mathbf{2}}$ & sd & $\mathbf{p}$ \\
\hline 20 ve alt1 & 20 & 94,03 & & & \\
$21-30$ aras1 & 96 & 82,06 & & & \\
$31-40$ aras1 & 38 & 98,14 & & & \\
$41-50$ aras1 & 20 & 96,18 & 8.235 & & .083 \\
51 ve üstü & 5 & 139,80 & & & \\
Toplam & 179 & & & & \\
\hline
\end{tabular}

Sürekli eğitim merkezi kursiyerlerinin, süreç boyutundan almış oldukları puanlar eğitim durumu grubuna bağlı olarak anlamlı farklılık göstermemektedir $\left(\mathrm{X}^{2}=.053, \mathrm{sd}=3, \mathrm{p}=.997\right)$. Bu durum, farklı eğitim durumu grubundaki kursiyerlerin süreç boyutu puanları eşittir şeklinde de açıklanabilir. Kruskal Wallis analizi kullanılarak kursiyerlerin süreç boyutuna ilişsin değerlendirmelerinde eğitim durumu değişkenine göre anlamlı bir fark olup olmadığına dair bulgulara Tablo 14'de görüldüğü biçimde ulaşılmıştır.

Tablo 14. Kursiyerlerin Süreç Boyutundan Aldıkları Puanların Eğitim Durumu Grubuna Bağlı Olarak Farklılı̆̆ını Gösteren Kruskal Wallis Analizi

\begin{tabular}{crrrrr}
\hline Yaš & $\mathbf{n}$ & Sira Ort. & \multicolumn{1}{c}{$\mathbf{X}^{\mathbf{2}}$} & sd & p \\
\hline Ortaögretim & 7 & 88,79 & & & \\
Önlisans & 8 & 86,25 & & & \\
Lisans & 118 & 90,08 & .053 & 3 & .997 \\
Lisansüstü & 46 & 90,63 & & & \\
Toplam & 179 & & & & \\
\hline
\end{tabular}

İkinci alt problemde amaç, örgütsel yapı ve süreç boyutları katılımcıların cinsiyet, yaş ve eğitim durumu değişkenine göre değerlendirilmiş ve anlamlı bir farklılık bulunmamıştır. Bu anlamda ilgili merkezlere yönelik katılım amaçlarında cinsiyet değişkeninin rol oynamadığı, toplumda ortaya çıkan eğitim ihtiyacında cinsiyet değişkeninin belirleyici olmadığı söylenebilir. Doğal olarak cinsiyet değişkenine göre bireylerin beklentileri örgütsel yapı ve süreç boyutunda da benzerlik göstermiş̧tir. Ayrıca yaş ve eğitim durumu değişkenine göre de amaç, örgütsel yapı ve süreç boyutunda anlamlı bir farklılık ortaya çıkmamıştır. Bu durum sürekli eğitim merkezlerinin örgütsel yapı ve süreç boyutuyla ilgili güçlü ve zayıf yönlerini açıkça ortaya koymaktadır denilebilir.

\section{Tartışma ve Sonuç}

Sürekli eğitim merkezleri yönetsel etkililiğinin kursiyer görüşlerine göre değerlendirildiği bu araştırmada tartışma ve sonuç bölümü amaç, örgütsel yapı ve süreç boyutları üzerinden yürütülmüştür.

\section{Amaç Boyutu}

Kursiyerler düzenlenen eğitimlerde kendi amaç ve beklentilerinin gözetildiğini ve bu eğitim hizmetleriyle birey, kurum ve toplum bakımından olumlu katkı sağlandığını belirtmişlerdir. Kursiyerlerin amaç boyutuna yönelik değerlendirmelerinde cinsiyet, yaş ve eğitim durumuna göre anlamlı bir farklılık görülmemiştir.

Örgüt yönetimlerinin katılımcı amaçlarını dikkate almasının yönetsel etkililik bakımından önemli olduğu düşünülecek olursa, bu durumun kursiyer değerlendirmeleri ile teyit edildiği söylenebilir. Toplumsal bir hizmet veren sürekli eğitim merkezlerinin toplumda kabul görmesini sağlamak için ilgili kursiyer amaçlarının 
gözetilmesi önem taşımaktadır. Argan’nın (2013) belirttiği gibi hedef kitlenin ihtiyaçlarına cevap vermenin başarıyı arttırmada ve amaca ulaşmada olumlu etkisi söz konusudur. Yöneticilerin katılımcıların amaçlarına ulaşmasını sağlaması yönetici yetkinlikleri adına olumlu bir gösterge olarak kabul edilmektedir (Armstrong, 2013). Eğitim örgütlerinde öğrenci çıktıları konusunda ortak bir anlayışın olması öğrenci başarısını olumlu yönde etkilemektedir (Rollie, 2007). Bu anlamda sürekli eğitim merkezlerinde amaç boyutunda ortak yaklaşımlar sergilenmekte ve eğitim programlarının başarısına dolayısı ile kurumun yönetsel etkililiğine olumlu katkı sağlanmaktadır denilebilir. Ayrıca bireylerin tercihlerinin oluşmasında hizmet aldıkları örgütün etik değerlerinin ve toplum yararına olan hizmetlerinin de rolü (Saran ve ark., 2011) vurgulanabilir. Bu anlamda kursiyerlerin aldıkları eğitimlerde kendilerine yönelik sağlanacak katkının yanı sıra topluma yönelik bir katkının da olacağını hissetmeleri yönetsel etkililik açısından önemli görülebilir. Örgütlerin yürüttüğü faaliyetlerde ana amaçlarını destekleyen pek çok amacın olması, amaçlarında çeşitliliğin görülmesi söz konusudur. Ekonomik amaçlara yönelik faaliyetlerin yanı sıra sosyal, kültürel, toplumla bütünleşme gibi amaçların olduğu faaliyetlerden de bahsetmek mümkündür (Argan, 2013). Özellikle ileri yaş grubunda yer alan kursiyerlerin yapmış olduğu değerlendirmelerden yola çıkarak böylesi etkinliklere erişebilmenin ve bu türden firsatları yakalayabilmenin önemli olduğu vurgulanabilir. Kısaca katılımcıların örgütte yer almalarını sağlayan gerekçelerin ve anlamlı gelen noktaların çeşitliliği örgüte olan ilgiyi arttırmaktadır denilebilir.

\section{Örgütsel Yapı Boyutu}

Kursiyerlerin sürekli eğitim merkezleri örgütsel yapısına yönelik değerlendirmeleri olumlu yönde olmuştur. $\mathrm{Bu}$ durum kursiyerlerin cinsiyet, yaş ve eğitim durumuna göre anlamlı bir farklılık göstermemiştir.

Örgütlerin amaçlarına ulaşmaları için en uygun örgütsel yapıyı kurmaları önemlidir. Verilen hizmetin niteliğini etkileyen faktörlerden birisi de mevcut örgütsel yapı olup, çözüm odaklı olması gerekir. Toprakçı ve Akçay'ın (2016) belirttiği gibi amaçları gerçekleştirecek örgütsel yapıyı kurmak ve eldeki kaynakları en verimli biçimde örgütsel yapı içerisine dâhil etmek önemlidir. Örgütlerin değişimleri yakından izlemesi ve uyum sağlayarak varlıklarını devam ettirmesi gereklidir (Demirtaş, Özdemir ve Küçük, 2016). Bu anlamda sürekli eğitim merkezlerinden eğitim hizmeti alan kursiyer profilinin geniş bir yelpazeyi kapsaması ve bu merkezlerde düzenlenen eğitim hizmetlerinin oldukça çeşitlilik göstermesi örgütsel yapı üzerinde bir baskı oluşturmaktadır denilebilir. Yaşam boyu öğrenme içeri düşünüldüğünde sürekli eğitim merkezlerinin diğer örgün eğitim kurumlarına göre daha dinamik ve özerk bir yapıda olmaları önem taşımaktadır. Bu araştırma kapsamında elde edilen kursiyer değerlendirmeleri, sürekli eğitim merkezlerindeki mevcut örgütsel yapının etkililiğini ortaya koymaktadır. Ancak danışma hizmetlerinin daha etkin verilmesi, planlanan eğitimlerin tanıtılması gibi bir takım çalışmaların ilgili örgütsel yapılar içerisinde daha etkin hale getirilmesi, beklentilerin karşılanması ve yönetsel etkililiğin sağlanması adına önemli olarak görülebilir.

\section{Süreç Boyutu}

Kursiyerler sürekli eğitim merkezlerinde yürütülen süreci öğretim elemanı, eğitim hizmetleri ve fiziki yapı bağlamında olumlu yönde değerlendirmişlerdir. Bu durum kursiyerlerin cinsiyet, yaş ve eğitim durumuna göre anlamlı bir farklılık göstermemiştir.

Yaşam boyu öğrenme kapsamındaki katılımcılar için alınan eğitime yönelik beklenti "sahnedeki bilgi” yerine "yanındaki rehber" (Longworth, 2003) şeklindedir. Bu anlamda ilgili merkezlerde görev yapan öğretim elemanlarının beklentileri karşılayan bir biçimde kursiyerlerin deneyim ve önceliklerini önemsedikleri görülmüştür. Örgüt yönetimlerinin süreç içerisinde kursiyerlerin eğitimsel ihtiyaçlarına cevap vermesi ve Biçerli'nin (2012) değindiği gibi kursiyer katılımını arttırmak için esneklik, program çeşitliliği vb. konularda düzenlemeler yapması etkililik noktasında katkı sağlamayla ilişkilendirilebilir. Kursiyerlerin yapmış olduğu değerlendirmelerden yola çıkarak verilen eğitimlerde belli bir planın uygulandığı ancak ortaya çıkan ihtiyaçlara yönelik bir takım esnekliklerin de sağlandığı söylenebilir. Süreç boyutunda fiziki imkânlara yönelik yapılan değerlendirmelerin öğretim elemanı ve eğitim hizmetleri alt boyutlarına göre daha düşük puan aldığ görülmektedir. Toplumlar içinde bulundukları dönemin gelişmelerine bağlı olarak eğitimle ilgili mekânları amaca uygun ve ideal bir biçimde gerçekleştirme çabasındadır (Uludağ ve Odacı, 2002). Eğitim ortamlarının fiziksel anlamda eğitimde yer alan paydaşların güdülenmelerini sağlayıcı, amaçlarını destekleyici ve işlerini kolaylaştırıcı biçimde oluşturulması, başarılı ve etkili sonuçlar almayı beraberinde getirecektir (Yıldırım, 2014). Bu manada yaşam boyu öğrenmeye yönelik eğitim hizmetlerinin verildiği mekânlar için çağdaş, güven verici, eğitim içi ve dışı zamanlarda ihtiyaçlara yetebilen, yetişkin zevk ve ölçütlerinin gözetildiği, ulaşım sıkıntısının yaşanmadığı yerler olmalıdır denilebilir. Eldeki zamanın ekonomik değerini vurgulamak suretiyle fiziki 
imkânların öğrenenlere mümkün olduğunca yakın (Biçerli, 2012) olmasından başlayarak, ilgili kurumların sahip olduğu diğer fiziki olanakların yaşam boyu öğrenmeye ve yetişkin ihtiyaçlarına ne yönde etki ettiği araştırma kapsamında gözden geçirilebilir.

\section{Teşekkür ve Bilgilendirme}

Bu çalışma "Üniversitelerdeki Yaşam Boyu Öğrenme Hizmetlerinin Yönetsel Etkinliğinin Değerlendirilmesi" adlı doktora tezinden elde edilmiştir. Bu anlamda bu tezin danışmanı olan Prof. Dr. R. Cengiz Akçay'a teşekkür ederim. 


\section{References}

Akar, N. (2017). Kişilik profilinin ve örgüt kültürünün bireysel yenilikçilik üzerine etkisi: kobi’ler üzerinde bir alan araştırması [The effect of personality profile and organizational culture to individual innovativeness: a field study on SME] (Yayınlanmış yüksek lisans tezi) [Published master thesis]. Trakya University Institute of Social Sciences, Edirne.

Armstrong, M. (2013). How To Manage People (3 ${ }^{\text {rd }}$ ed.). London: Kogan Page Limited.

Argan, M., T. (2013). Etkinlik kavramı ve türleri [Concept and types of activity]. Ertan, H. (Ed.), Etkinlik Yönetimi [Activity Management] (2. bs.) [2 ${ }^{\text {nd }}$ ed.] (pp. 2 - 31). Eskisehir: Anadolu University Open Education Faculty Publications.

Arslan, H. (2010). How to improve effectiveness in public schools. $2^{\text {nd }}$ International Symposium on Sustainable Development, $\quad(301 \quad-\quad 310), \quad 8 \quad-\quad 3010$. http://eprints.ibu.edu.ba/711/1/ISSD2010Socialscience_p301-p310.pdf (04.09.2013).

Biçerli, M. K. (2012). Hayat boyu öğrenmenin önemi ve sistemleştirilmesi [The importance and systematization of lifelong learning]. Hayat Boyu Öğrenme Kültürü Ve Mesleki Eğitim Sempozyumu: Uluslararası Sempozyum Bildirileri [Lifelong Learning Culture and Vocational Education Symposium: International Symposium Reports], (pp. 39 - 44), 16 - 17 June 2012. Istanbul: Istanbul Metropolitan Municipality Arts and Vocational Training Courses Ismek Publications.

Bulur, N., Ulaş, Ü., H., Ulaş, M. and et al. (2018). Malatya ili halk eğitim merkezi usta öğreticilerin kurs programı kazanımlarının değerlendirilmesi [Assesment of malatya public educatıon center's qualified workers' training achievement in training programme]. Journal of Research in Education and Teaching, 7 (3). http://www.jret.org/FileUpload/ks281142/File/14.naci bulur.pdf (02.10.2018).

Bütüner, S., Ö. (2008). Kitap incelemesi - sosyal bilimler için veri analizi el kitabı [Book review - data analysis handbook for social sciences]. Elementary Education Online, 7 (1), 6 - 8. http://ilkogretimonline.org.tr/vol7say1/v7s1k4.pdf (06.11.2016).

Büyüköztürk, Ş. (2005). Anket geliştirme [Survey development]. The Journal of Turkish Educational Sciences, 2 (3), 133 - 151. http://www.tebd.gazi.edu.tr/arsiv/2005_cilt3/sayi_2/133-151.pdf (24.04.2013).

Demirtaş, Z., Özdemir, T., Y. ve Küçük, Ö. (2016). Okulların bürokratik yapısı, örgütsel sessizlik ve örgütsel sinizm arasındaki ilişki [Relationships between bureaucratic structure of schools, organizational silence and organizational cynicism]. Educational Administration: Theory and Practice, 22 (2), 193 - 216. http://www.kuey.net/index.php/kuey/article/view/kuey.2016 .008/pdf (21.12.2016).

Drucker, P., F. (1993). Educated person. Post Capitalist Society (1 ${ }^{\text {st }}$ ed.) (pp. 191 - 198). New York: Routledge. http://books.google.com.tr/books?id=IYVBmM5z69cC\&

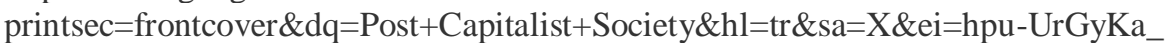
Z0QXoh4CgDw\&redir_esc=y\#v=onepage\&q=educated\&f=false (18.08.2013).

Erdem, A., R. (2005). Üniversitenin var oluş nedeni (üniversitenin misyonu) [The reason for the existence of the university (the mission of the university)]. Pamukkale University Journal of Education, 17, 75 - 86. http://pauegitimdergi.pau.edu.tr/

Makaleler/1384119108_11\%c3\%9cN\%c4\%b0VERS\%c4\%b0TEN\%c4\%b0N\%20 VAR\%20OLU\%c5\%9e\%20NEDEN\%c4\%b0.pdf (06.04.2013)

EUA - European University Association (2008). European universities' charter on lifelong learning. Brussels: University Association.

http://www.eua.be/fileadmin/ user_upload/files/Publications/European_Universities_Charter_on_Lifelong_learning.pdf (25.04.2013).

Güleç, İ., Çelik, S. ve Demirhan, B. (2012). Yaşam boyu öğrenme nedir? Kavram ve kapsamı üzerine bir değerlendirme [What is lifelong learning? An evaluation on definition and scope]. Sakarya University Journal of Education, 2 (3), 34 - 38. http://www.suje.sakarya.edu.tr/index.php/suje/article/view/22/22 (05.01.2013).

Hoy, W., K. ve Miskel, C., G. (2012). Eğitim Yönetimi: Teori, Araştırma ve Uygulama [Educational Administration: Theory, Research, and Practice] (Trans. Ed. Turan, S.). Ankara: Nobel Publications. 
Jarvis, P. (2007). Lifelong learning in the social context. Globalisation, Lifelong Learning and the Learning Society (pp. 1 - 21). Oxon: Routledge. http://www.ebookstore.tandf.co.uk/ (24.09.2012).

Karasar, N. (2012). Bilimsel Araştırma Yöntemi [Scientific Research Method] ( 24. bs.) [24 ${ }^{\text {th }}$ ed.]. Ankara: Nobel Publications.

Karslı, M., D. (2004). Yönetsel Etkililik [Managerial Effectiveness] (2. bs.) [2 ${ }^{\text {nd }}$ ed.]. Ankara: Pegem Academy.

Kaya, H., E. (2014). Küreselleşme sürecinde yaşam boyu öğrenme ve yetişkin eğitimi gerçeği [Lifelong learning and adult education reality within the scope of globalization]. Akademik Incelemeler Dergisi [Journal of Academic Inquiries], 9 (2), 91 - 111. http://dergipark.gov.tr/download/article-file/17914 (03.10.2018).

Longworth, N. (2003). Lifelong Learning in Action (1 $1^{\text {st }}$ ed.). London - Sterling / Virjinya: Kogan Page Limited.

MacPhail, J., S. (2008). The OECD, Neoliberalism, and the Learning City: Promoting Human Capital in the Guise of Lifelong Learning (Published master thesis). Mount Saint Vincent Üniversitesi, Nova Scotia, Canada. http://www.swaraj.org/shikshantar/resources_macphail.htm (03.12.2013).

Öner, A. (2014). Hayat boyu eğitimin sağlanmasında halk eğitimi merkezlerinin değerlendirilmesi: Yenișehir Halk Eğitimi Merkezi örneği. örneği [The assessment of public education centers for providing lifelong education: Yenişehir Education Center application]. Yüksek Lisans Tezi, Toros Üniversitesi Sosyal Bilimler Enstitüsü, Adana.

Özengi, M. (2017). Halk ĕgitimi merkezlerinin kursiyer görüşlerine göre değerlendirilmesi: Amasra halk ĕgitimi merkezi örneği [Evaluation by student thoughts of public education centers: the case of Amasra education center] (Yayınlanmış yüksek lisans tezi) [Published master thesis]. Bartın University Institute of Educational Sciences, Bartın.

Robbins, S., P. ve Judge, T. A. (2013). Örgütsel Davranış [Organizational Behaviour] (Trans. Ed. Erdem, İ.). Ankara: Nobel Publications.

Rollie, D., L. (2007). Preface - the problem of continuous school improvement. Dawley, W., D. ve Rollie, D., L. (Ed.), The Keys To Effective Schools ( $2^{\text {nd }}$ ed.). London: Sage Publications Ltd.

Saran, M., Coşkun, G., Zorel, F., İ. ve Aksoy, Z. (2011). Üniversitelerde sosyal sorumluluk bilincinin geliştirilmesi: ege üniversitesi topluma hizmet uygulamaları dersi üzerine bir araştırma [Improving the consciousness of social responsibility at universities: a research on lesson of social service practice at Ege University]. Journal of Yasar University, $2011 \quad 22(6), \quad 3732 \quad$ - 3747. http://content.ebscohost.com/ContentServer.asp?T=P\&P=AN\&K=85900893\&S=R\&D=a9h\&EbscoContent= dGJyMNLr40SeqK44wtvhOLCmr06ep7RSsaq4Sa6WxWXS\&ContentCustomer=dGJyMPGotlG0qrZKuePf geyx43zx (20.12.2016).

Soran, H., Akkoyunlu, B. ve Kavak, Y. (2006). Yaşam boyu öğrenme becerileri ve eğiticilerin eğitimi programı: Hacettepe Üniversitesi örneği [Life-long learning skills and training faculty members: a project at Hacettepe University]. Hacettepe University Journal of Education. 30, 201 - 210. http://www.efdergi.hacettepe.edu.tr/ 200630HALUK\%20SORAN.pdf (06.04.2013).

Sökmen, A, Benk, O. ve Gayeker, S. (2017). Örgüt kültürü, örgütsel vatandaşlık davranışı ve örgütsel bağlılık ilişkisi: bir kamu kurumunda araştırma [The Relationship Among Organizational Culture, Organizational Citizenship Behavior and Organizational Commitment: A Study in A Public Organization]. Gazi Üniversitesi İktisadi ve İdari Bilimler Fakültesi Dergisi [Gazi University Journal of Economics and Administrative Sciences], 19 (2), 415 - 429. http://www.iibfdergisi.gazi.edu.tr/index.php/iibfdergisi/article/view/1443/768 (03.10.2018).

Şahin, B. (2012). Metodoloji [Methodology]. Tanrı̈ŏğen, A. (Ed.), Bilimsel Araştırma Yöntemleri [Scientific Research Methods] (3. bs.) [3 ${ }^{\text {rd }}$ ed.] (pp. 109 - 130). Ankara: An1 Publications.

Şimşek, A. (2012). Araştırma modelleri [Research models]. Şimşek, A. (Ed.), Sosyal Bilimlerde Araştırma Yöntemleri [Research Methods in Social Sciences] (1. bs.) [1 ${ }^{\text {st }}$ ed.] (pp. 80 - 107). Eskisehir: Anadolu University Publications. 
Taşçı, D., Aydın, C., H., Kumtepe, E., G. and et al. (2015). Eskişehir'de yaşam boyu öğrenme başlığı altında yetişkin eğitiminin analizi [Analysis of lifelong adult education in Eskişehir]. Selçuk Ün. Sos. Bil. Ens. Der. 34, 197 - 211. http://dergisosyalbil.selcuk.edu.tr/susbed/article/view/1168/1042 (02.10.2018).

Toprakçı, E. ve Akçay, A. (2016). Türkiye'de kamu yararına çalışan derneklerin eğitim faaliyetlerinin yönetimi ve denetimi (yasal belgeleri temelinde nitel bir analiz) [Administration and supervision of the educational activities of public benefit associations in Turkey (a qualitative analysis based on the legal documents)]. Cumhuriyet International Journal of Education - CIJE, 5 (1), 2016, $29 \quad-\quad 52$. http://www.cijeonline.com/index.php/cije/article/view/154/213 (21.12.2016).

Uludağ, Z. ve Odacı, H. (2002). Eğitim öğretim faaliyetlerinde fiziksel mekân [Physical conditions in educational activities]. Millî Eğitim Dergisi [Journal of National Education], 29, 153 - 154. http://dhgm.meb.gov.tr/yayimlar/dergiler/Milli_Egitim_Dergisi/153-154/uludag.htm (20.02.2014).

Ünal, C. (2006). Bazı AB ülkelerindeki halk eğitim ve mesleki eğitim uygulamaları ve ülkemizin halk eğitim ve mesleki eğitim uygulamaları açısından AB'ye uyumlulaştırılması örneği [The assessment of public education centers for providing lifelong education: Yenişehir Education Center application]. Yüksek Lisans Tezi, Marmara Üniversitesi Eğitim Bilimleri Enstitüsü, İstanbul.

Ünal, F., Kalçık, C. ve Satuk, M. (2016). Halk eğitim kurslarının, kadın katılımcıların yaşam boyu öğrenme becerilerine katkısının değerlendirilmesi [A review on the contributions of community education centres to the lifelong learning skills of female participants]. International Periodical for the Languages, Literature and

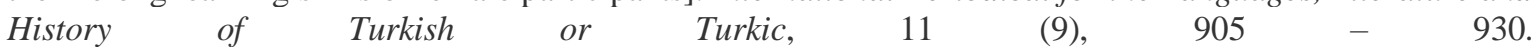
http://www.turkishstudies.net/Makaleler/529217481_46\%C3\%9CnalFatma-vd-egt-905-930.pdf (03.10.2018).

Wissema, J., G. (2009). Third Generation University: Managing the University in Transition. Cheltenham: Edward Elgar Publishing Limited.

Yancar, M. (2014). Halk eğitimi merkezlerinde düzenlenen mesleki ve teknik kurslara devam eden yetişkinlerin bu kurslart tercih etme nedenleri ve kursa ilişkin beklentileri (Menemen örneği) [The reasons of the adults participating in vocational and technical courses in public education centers to choose these courses and their expectations related to the courses]. Yüksek Lisans Tezi, Okan Üniversitesi Sosyal Bilimler Enstitüsü, İstanbul.

Yıldırım, R. (2014). Sınıfin fiziksel düzenini oluşturma [Creating the physical layout of the class]. Arslan, H. (Ed.), Sinıf Yönetimi [Classroom Management] (1. bs.) [1 ${ }^{\text {st }} \mathrm{ed.]}$ (pp. 37 - 72). İstanbul: Paradigma Academy Publications.

Yıldırım, R. (2017). Üniversitelerdeki Yaşam Boyu Öğrenme Hizmetlerinin Yönetsel Etkililiğinin Değerlendirilmesi [Evaluation of Managerial Effectiveness of Lifelong Learning Services in Universities] (Yayınlanmış doktora tezi) [Published doctoral thesis]. Canakkale Onsekiz Mart University Institute of Educational Sciences, Canakkale.

Yusuf, S. (2011). Üniversite - endüstri ilişkileri [University - industry associations]. Yusuf, S. \& Nabeshima, K. (Ed.), Üniviversiteler Ekonomik Büyümeye Nasıl Katkıda Bulunur [How Universities Promote Economic Growth] (Kadri Yamaç, trans.) (1. bs.) [1 $\left.1^{\text {st }} \mathrm{ed}.\right]$ (pp. 1-24). Ankara: Eflatun Publications. 